\title{
ARTICLE
}

\section{Ties between steppe and peninsula: Comparative perspective of the Bronze and Early Iron Ages of Mongolia and Korea}

Jamiyan-Ombo Gantulga

The department of Bronze and Early Iron Age, Institute of Archaeology, Mongolian Academy of Sciences, Ulaanbaatar, Mongolia

ARTICLE INFO: Received: 26 Jun, 2020; Accepted: 21 Nov, 2020

Abstract: This article describes the results of a comparative study of some monuments (settlement, dolmen, rock art) and some artifacts (pottery, arrowhead, dagger, bronze mirror, bead, whetstone) of the Bronze and Early Iron Ages of Mongolian steppe and Korean Peninsula. The comparative study sought to clarify the external and internal structures of the monuments, as well as the burial practices. In the case of artifacts, their materials and functions were considered.

Keywords: Monument; artifact; Bronze Age; Early Iron Age; Mongolia; Korea;

\section{INTRODUCTION}

The study of funerary and ritual monuments and rock art of the ancient Mongolian nomads is very important for research on the history of the ancient history of Eurasia. It is more than a century since archaeological study began in Mongolia. Scientists from different countries have gathered extensive archaeological materials and have made important scientific discoveries of ancient cultures of the ancient populations of Inner Asia. However, until recently, monuments (Afanas'evo culture, Khemceg culture, Mönkh-Khairkhan culture, Saisaishaped graves, Figure-shaped grave, Khirgisuur, Deer stone, Slab grave, Pazyryk tomb, Grave of Chandmani-Sagil and Rock Art) of the Bronze and Early Iron Age nomads of
Mongolia have not become the object of special study (Table 1).

Scholars have highlighted some similar characters on principal monuments and some artefacts of Bronze and Early Iron Ages of Korea and Altai Mountain region, Siberia, and Mongolia. For example, Jeulmun pottery bears basic design and form similarities to that of Mongolia, Russian Maritime Province, and the Amur and Sungari River basins of Manchuria, the Jōmon culture in Japan and with the Baiyue in Southern China and Southeast Asia. Also, a very interesting site is Songguk-ri in Buyeogun. Songguk-ri is a settlement with burial site that is important in the study of Korean prehistory, in particular, of great interest is the site of Middle Mumun Culture in Southern Korea.

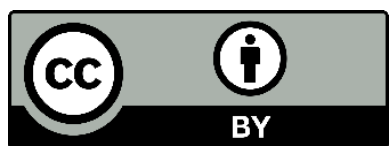

The Author(s). 2020 Open access This article is distributed under the terms of the Creative Commons Attribution 4.0 International License (https://creativecommons.org/licenses/by/4.0/), which permits unrestricted use, distribution, and reproduction in any medium, provided you give appropriate credit to the original author(s) and the source, provide a link to the Creative Commons license, and indicate if changes were made. 
For this reason, my research interest is to compare similar monuments and artifacts of Central Asia; in this way we can find ways to resolve some disputed problems of interaction between the ancient populations of Korea and Mongolia from the view point of monuments, characters, development perspective and traditions.

Over the recent years, there has been a lot of news about findings of numerous sites of Bronze and Early Iron Ages in the Korean Peninsula, dating of which is clearly established
(Table 2). It is obvious that we should investigate not only sites and findings of Bronze and Early Iron Ages, but also as many sites and findings as possible in order to undertake efficient comparative investigation.

Histography of Mongolia and Korea. Many archaeological sites of Bronze and Early Iron Ages have been so far found in Mongolia and Korea. The following comparative table provides an overview of the relevant periods and archaeological cultures:

Table 1. Chronological table of the Bronze and Early Iron Ages of Mongolia

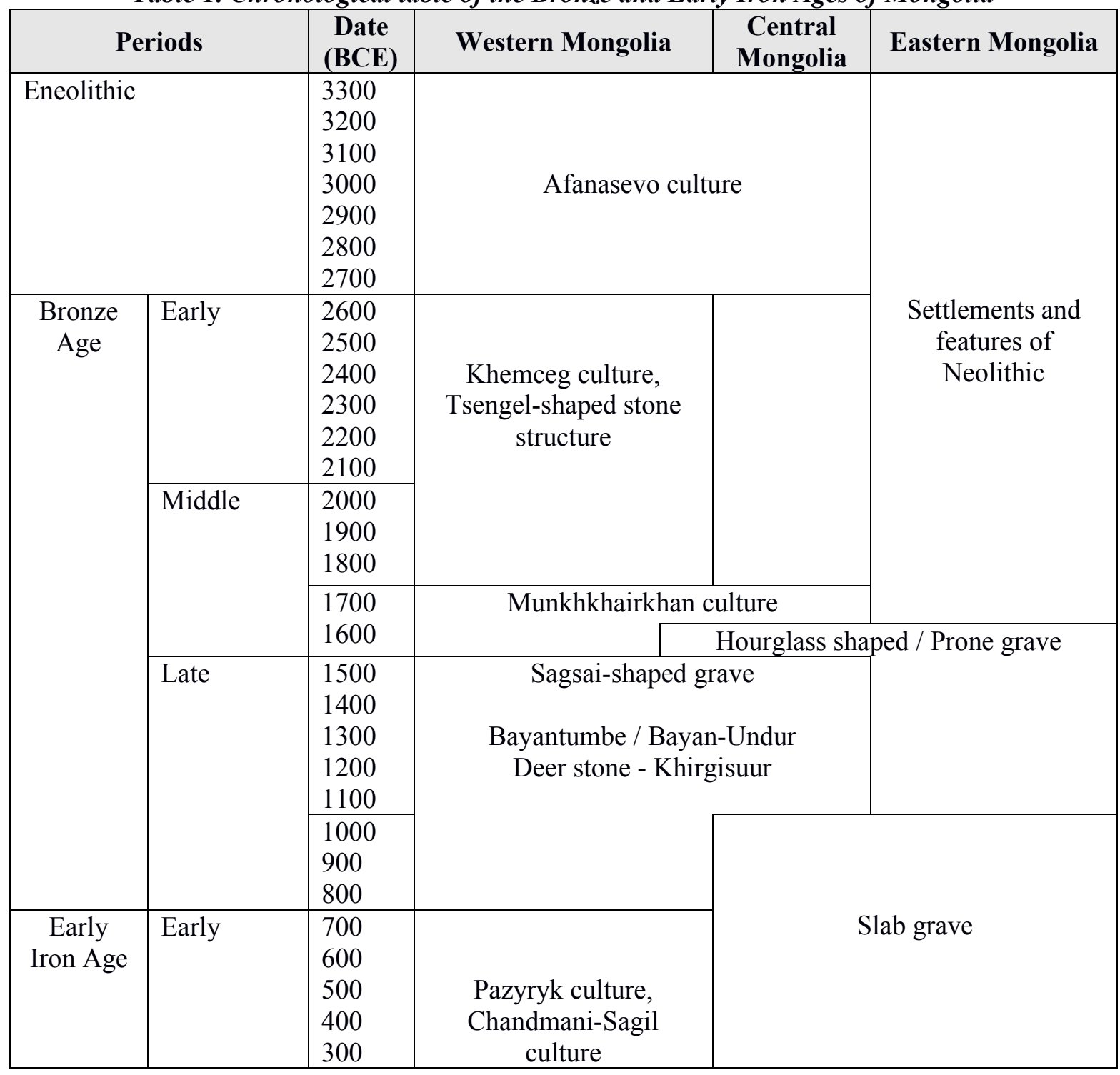


Table 2. Periodization schemes for the Korean Peninsula [1]

\begin{tabular}{|c|c|c|c|c|}
\hline Date & Rhee and Choi (1992) & Lee S.J. (1998) & Bale a & (2006) \\
\hline 600 & \multirow{3}{*}{ Mumun } & \multirow{2}{*}{ Early } & \multirow{3}{*}{$\begin{array}{l}\text { Mumun } \\
\text { Pottery }\end{array}$} & Late Mid \\
\hline 700 & & & & Early \\
\hline 800 & & & & Early \\
\hline 1500 B.C. & Jeulmen & Neolithic & \multicolumn{2}{|c|}{ Jeulmen } \\
\hline
\end{tabular}

Note: The shaded area indicates the period of this study (c. 1100-550 B.C.E.)

\section{MATERIALS AND METHODS}

The main materials of this study were some monuments (settlement, dolmen, rock art) and artifacts (pottery, arrowhead, dagger, bronze mirror, bead, whetstone) of the Mongolian and Korean Bronze and Early Iron Ages. Their similarities and differences were

\section{RESULTS AND DISCUSSION}

Comparative analyses of monuments and artifacts performed applying archaeological comparison and descriptive methods. It is difficult to compare the monuments and findings of Bronze and Early Iron Ages of distant areas, but we have found some similar elements. Originally, I wanted to base my study mainly on the Songguk-ri site of Buyeo for comparative purposes, however, I decided to incorporate all types of monuments, some artifacts of settlements, graves and rock art sites of ancient Korea.

Buyeo region is a special area on the Korean Peninsula, on the World Heritage List such as the Baekje Historic Areas (Gongsanseong fortress, Royal Tombs, Ungjin capital, Busosanseong fortress, Jeongnimsa temple site, Naseong city wall, Sabi capital, and Mireuksa temple site), which are located in this region. The people of the Buyeo region developed a unique bronzeware culture known as "Songguk-ri culture" or "Korean-type bronze dagger culture", incorporating influences from the northwestern region of the Korean Peninsula, the Han River basin and the northeastern region of China. The rich culture identified by comparative study methodology. The comparative study sought to clarify the external and internal structures of the monuments, as well as the burial practices. In the case of artifacts, their materials and functions were considered.

of Buyeo spread down through the southern region of the Korean Peninsula.

\section{Comparison of monuments}

Songguk-ri site

This site is of highest academic significance in the archaeology of Korea. Field campaigns at Songguk-ri site were initiated in 1975 and since, as of 2017 , a total of 22 fieldworks had been conducted. It is the most intensively studied prehistoric site in Korea. Songguk-ri is a source of new archaeological concepts such as "Songguk-ri Assemblage", "Songguk-ri Type Pottery and Dwelling" and even "Songguk-ri Culture". Multi-component structures, dating from the Bronze Age to Chosun dynasty through the Baekje and Goryeo dynasties were discovered from this site. Most of the structures belong to the Bronze Age, including pit-houses, stone cist burials, jar coffins and palisades [2] (Fig. 1, 2). Groups of pit-houses were found in various spots in an area of almost $100,000 \mathrm{~km}^{2}$. About 50 pithouses were excavated at Songguk-ri. Pottery that is typically found in the Late Middle Mumun (c. 700-550 B.C.) was unearthed from 
the pit-houses, but some pit-houses may date to the Late Mumun period. The site also contains a high-status stone cist burial with a Liaoningstyle bronze dagger, a number of large tubularshaped greenstone ornaments, and a finelymade ground stone dagger. A number of jarburials have been unearthed from the site.
Also, findings at the site included stone tools, such as triangular harvesting knives, grooved adzes, arrowheads, polished daggers, spindle whorls, axes, and chisels. Therefore, carbonized grain jar of rice was discovered, suggesting that rice was being cultivated at the site $[3,4,5,6,7]$.

\begin{tabular}{|l|c|c|c|c|c|}
\hline Classification & I type & II type & III type & IV type & V type \\
\hline Dwelling & 25 & 27 & 25 & 12 & 6 \\
\hline Average Profile and Diameter & $4.077 \mathrm{~m}$ & $4.672 \mathrm{~m}$ & $5.082 \mathrm{~m}$ & $6.093 \mathrm{~m}$ & $7.667 \mathrm{~m}$ \\
\hline Capacity & $13.1 \mathrm{~m}^{2}$ & $17.1 \mathrm{~m}^{2}$ & $20.3 \mathrm{~m}^{2}$ & $29.2 \mathrm{~m}^{2}$ & $46.2 \mathrm{~m}^{2}$ \\
\hline Number of people & 3 & 5 & 7 & 9 & 11 \\
\hline
\end{tabular}

Figure 1. Capacity and dimension of dwelling of Songguk-ri site [23]

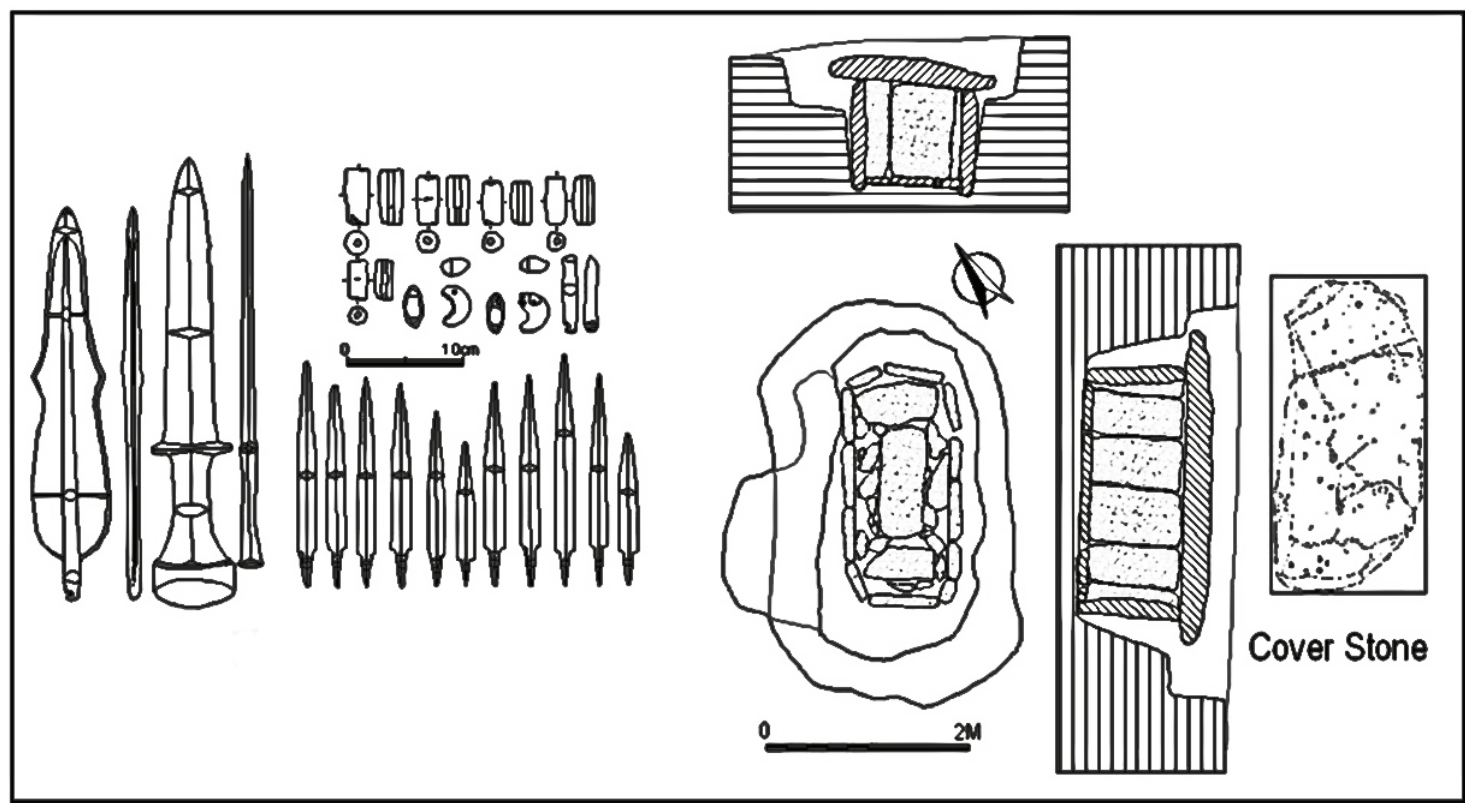

Figure 2. Tomb (Stone cist) No. 1 of the Songguk-ri site and artifacts [24]

Similar monuments are not available in Mongolia, but there are some identical elements such as stone cists and some artifacts. For example, the internal structure of stone cist is very similar to the internal structures of Khemtseg culture's graves in Western Mongolia [8]. The cover stones, fence and floor of the Khemtseg culture graves are similar to the stone cist (Fig. 3, 4). The stone cist is positioned under the covering-stones, at the central part of the surrounding fence, and it is made in the following manner: the cover stone is buried deep with a cryptic stone fence and then covered by some flat stones.

But the external structures and artifacts of these monuments are very different. Also, these monuments are far from each other and the difference is about 2000 years. 

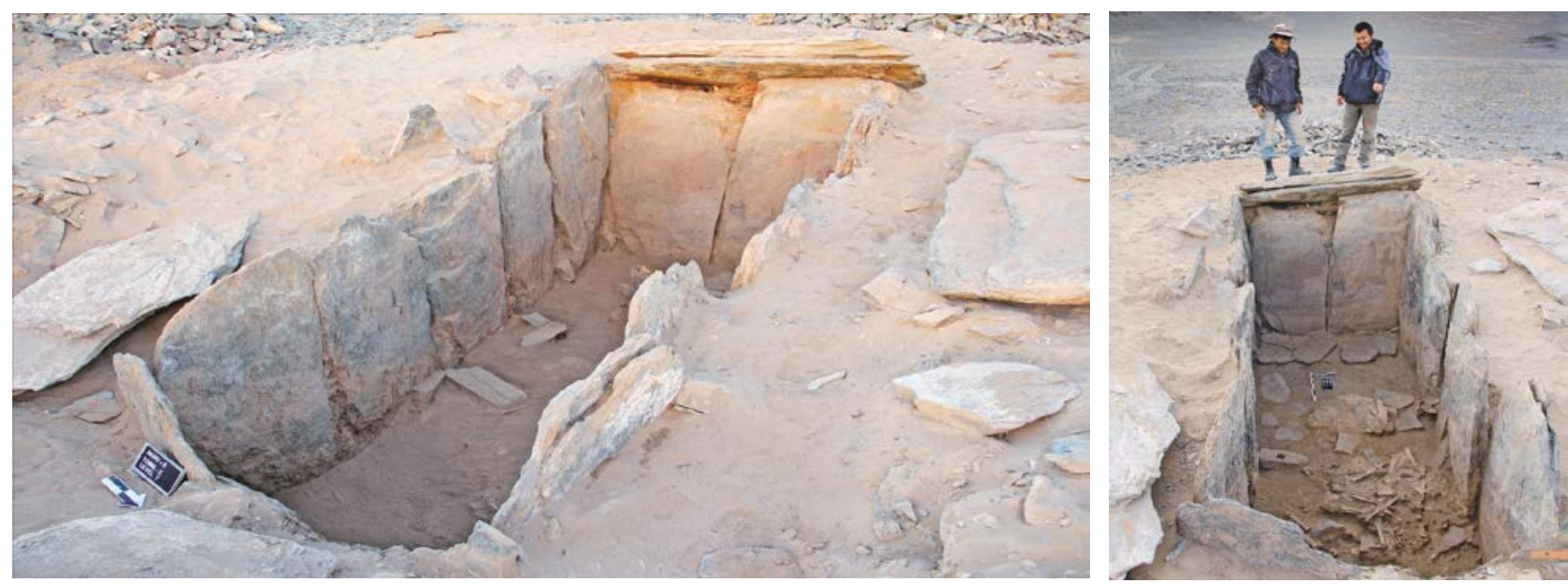

Figure 3. Stone fence and burial of Khemtseg culture, Avyn Khukh Uul, Bulgan, Khovd [8]

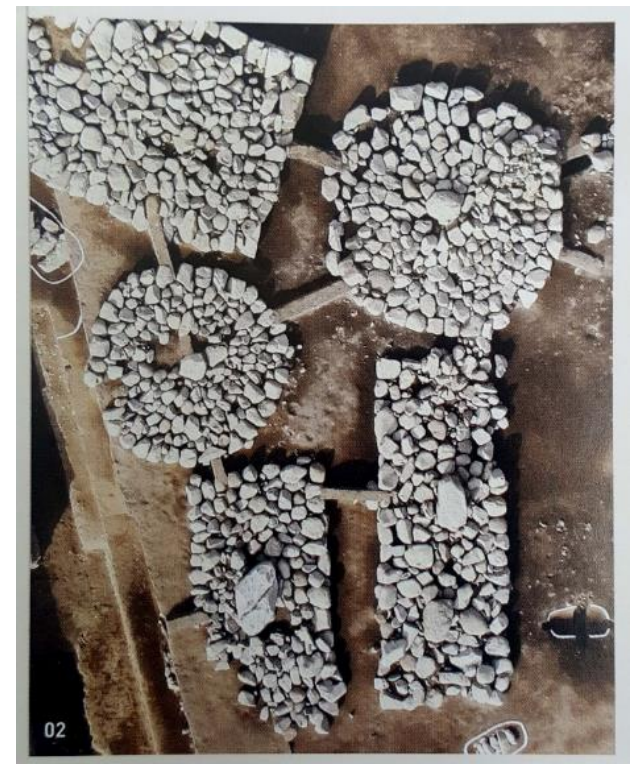

Dolmens of Maechon-ri site
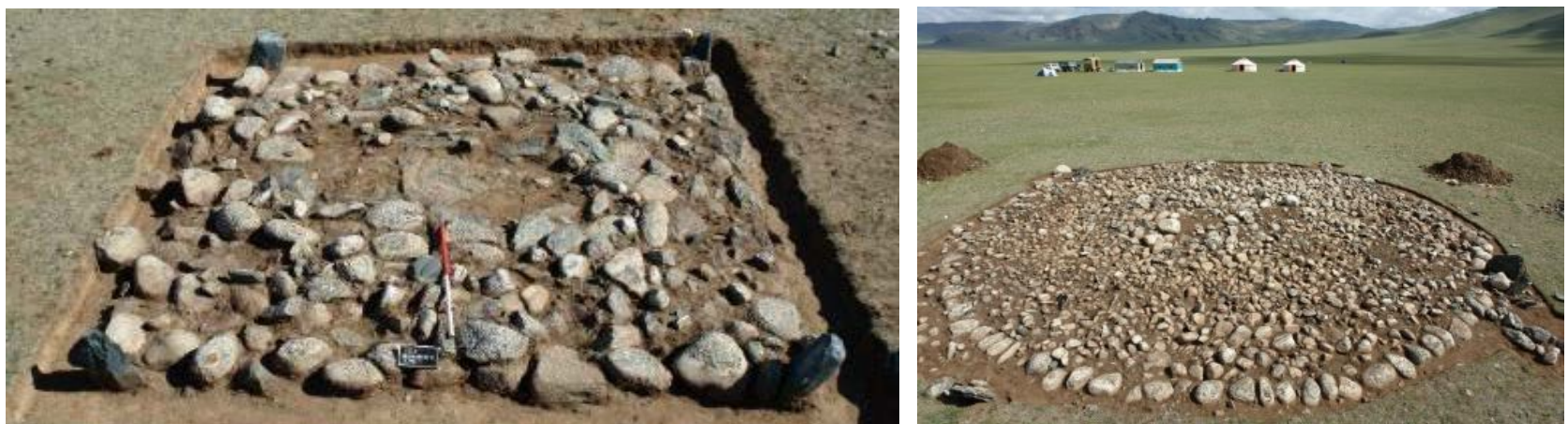

Sagsai-shaped graves, Tsagaan Asga site

Figure 4. Comparison of external structure of Dolmens and Sagsai-shaped graves 


\section{Dolmen}

Dolmen, constructed as a prehistoric stone grave structure, is an important part of the worldwide megalithic cultural tradition, which includes dolmens, menhirs (Standing stones), tombs with multiple burials (chamber tombs, passage graves, collective tombs, and gallery graves) and stone alignments.

Presently, only two types of megalithic structures, namely the dolmens and menhirs, are found on the Korean Peninsula. Korea has the largest number of dolmens in Northeast Asia, and the dolmens are the most conspicuous feature of Korea's prehistoric cultural remains. In recent years, more than 12,000 dolmens have been identified in South Cholla province alone. Korean dolmens are broadly classified into three types: Northern type, Southern type, and Capstone type. The most common artifacts associated with the Korean dolmens are polished stone daggers and stone arrowheads. Other artifacts include polished stone axes, stone chisels, semi-lunar shaped stone knives, grooved stone adzes, stone spears, grinding stones, and spindle whorls, as well as, potteries and bronze implements [9] (Fig. 5, 6).
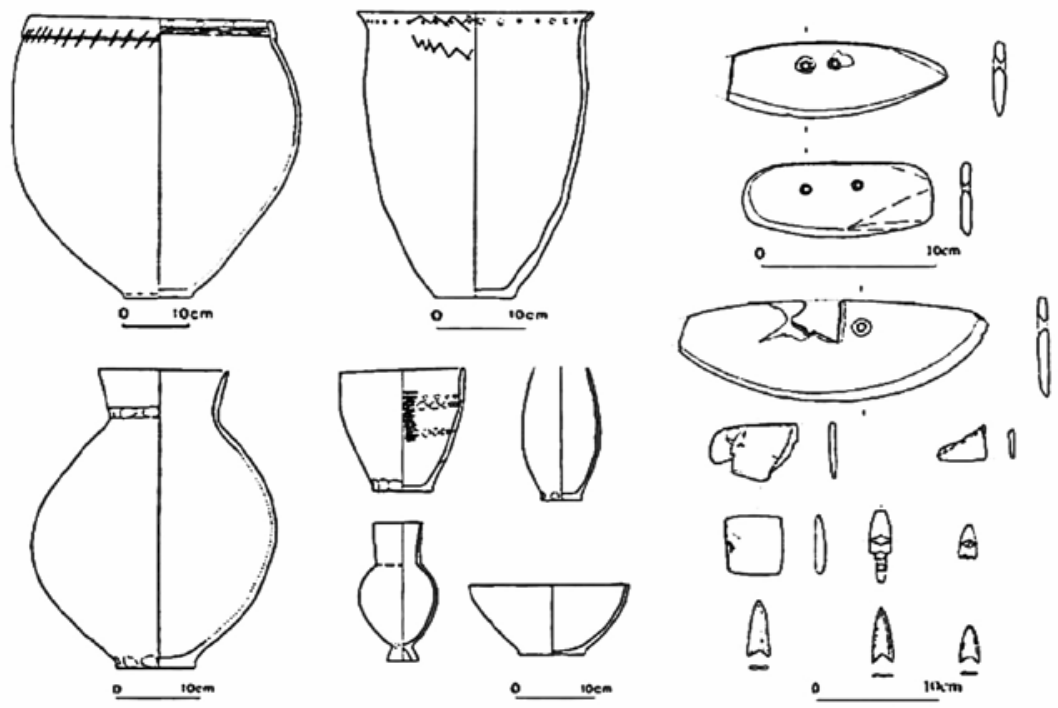

Figure 5. Artifacts of Dolmen, Gangneung Kyo Dong [25]

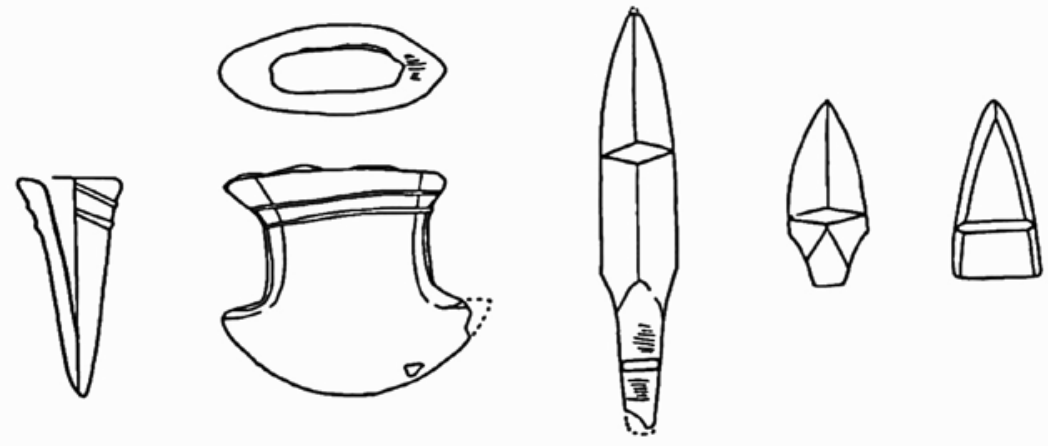

Figure 6. Artifacts of Dolmen, Gangneung Choyang-dong [25]

External structure. Although Mongolia and Korea are geographically far from each other, there are similar tombs that were made almost at the same time (Bronze Age). For example, in Korea, graves at Maechon-ri site in Sancheon are similar to Mongolian Sagsai graves, which for example, have been excavated at Tsagaan Asga in Bayan-Ulgii province. At both sites, the external shape and external structure of the tombs are very identical. There are rectangular and round shaped tombs, and especially, round shaped tombs are quite similar. 
Both sites contain several rectangular and round shaped tombs and covered by stones. There is no special line or order between rectangular or round shape. According to Tsagaan Asga site excavation, the outer shape of the cover (round, rectangular or square) does not correspond to the gender of the person buried in it, although the size of the cover does seem to correspond with markers of social status [10].

Also, on the central part of the stone covering, the placement of a bigger stone is typical for the Dolmen type, but also Sagsai graves display oftentimes some similarity as a bigger white stone appears to have been intentionally placed on the dark-colored covering stones, or a dark-colored stone was placed on a light-colored covering. But Sagsai tombs have a different characteristic, that is, they have stone-stelae on four sides (Fig. 4).

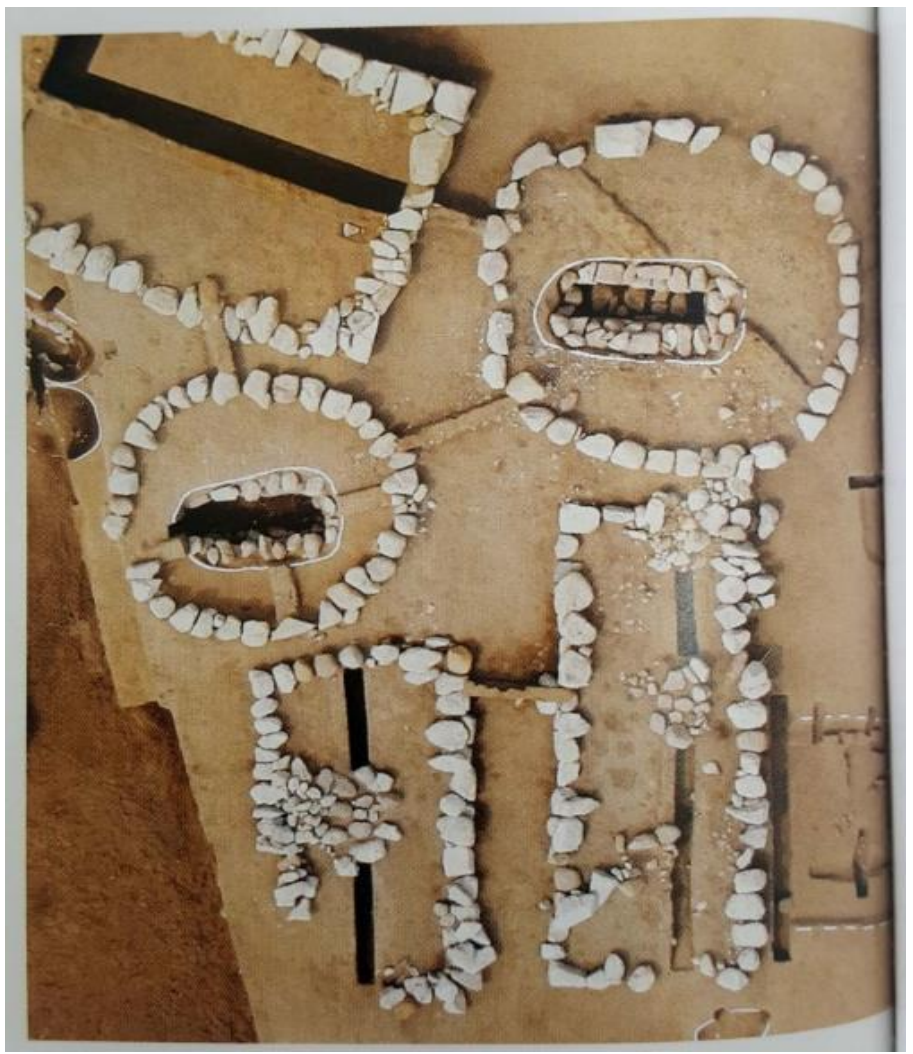

Internal Structure. The internal structure is also similar: the buried cist is positioned under the covering-stones, at the central part of the surrounding fence or frame. Moreover, it is made in several ways: under the cover of river cobbles, on the ground surface surrounded by a stone fence, or buried deeply with a cryptic stone fence and then covered by some flat stones (Fig. 7, 8).

Compared to Dolmens, artifacts are uncommon in these graves, but occasionally pieces of potteries, stone tools, stone headrests, and little remains of paint (ochre) have been found. But in Sagsai-shaped graves, human remains have been extraordinarily preserved, and with this advantage, genetic, isotopic, pathologic, and radiocarbon, etc., various natural scientific analyses can be performed. The Sagsai graves date from the Middle to the Late Bronze Age, 1500-980 BCE.
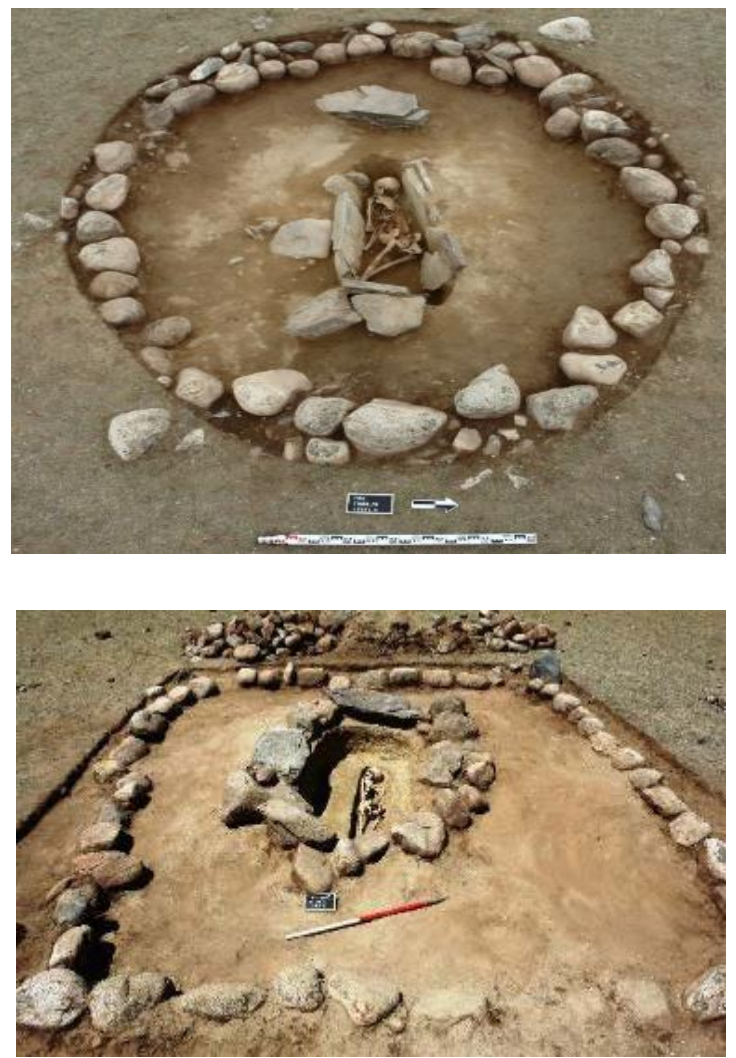

Figure 7. Comparison of internal structure of Dolmens and Sagsai-shaped graves 

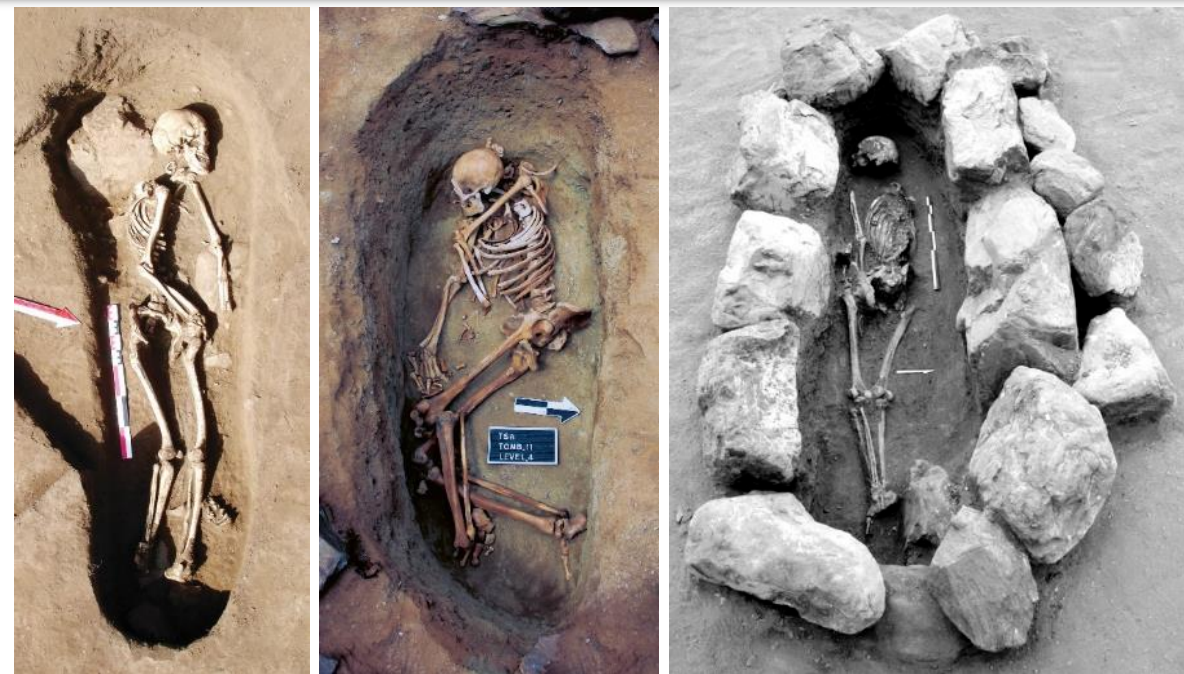

Figure 8. Sagsai-shaped graves interior structure and position of the deceased

\section{Rock art}

Rock art is one important component of the Bronze and Early Iron Age cultures. Rock art is an invaluable (pre) historical source, because it is a figurative reflection of religious beliefs, art, and language of the people who lived in a specific time and environment. Moreover, rock art carries not only people's belief, symbolism, and mythology, but is also a sign of their mentality. One of the monuments in the comparative study is rock art.

Until now more than 30 petroglyph sites have been found in Korea [11].

About one half of all prehistoric Korean petroglyphs fall into the same category as the Yangjeon-ri engravings in Goryeong, Gyeongsangbuk-do. In contrast, the Cheonjeon-ri and Bangudae engravings in the Daegok-ri petroglyphs depict animals and humans in detail. Especially the depictions of the Cheonjeon-ri panel from the Iron Age, which contain abstract patterns as its main images and detailed line carvings have never been found elsewhere on the Korean Peninsula. Together with the Bangudae petroglyphs they are a representative form of prehistoric Korean art. The Bangudae and Cheonjeon-ri petroglyph sites along with historical and cultural scenery were registered on the World Heritage Tentative List in 2010 under the title of the
"Daegokcheon Stream Petroglyphs" [12] (Fig. $9,10)$.

According to research, the Bangudae and Cheonjeon-ri Petroglyphs are presumed to be older than the Yangjeon-ri-type engravings. Therefore, the oldest engravings found in the Bangudae rock art can be regarded as the starting point of all Korean petroglyphs. As for the figures, the Bangudae stone contains both human and animals, most of which are whales. The whale images are rare in any country, and they illustrate the crucial importance of whaling in the prehistoric era. Nearly 300 figures depicting land and sea animals, as well as whale-hunting scenes, are found engraved on the wall spanning 10 by $3 \mathrm{~m}$. The engravings depict a total of 200 etchings, including figures of land animals (deer, tigers, wild boars, etc.), hunting scenes, sea animals (whales, seals, sea turtles), boats and fishermen. The Bangudae Petroglyphs are important reflections of the hunting rituals and religious arts of Korea's prehistoric era and serve as an important clue to the lifestyle and customs of ancient Koreans $[13,14]$. Scenes depicting hunting, livestock and herding are often found on petroglyphs in Mongolia, Siberia, and northern China, and very detailed images of wolves or tigers attacking livestock and people responding with arrows or spears are vividly depicted on the engraved stones (Fig. 9, 10). 

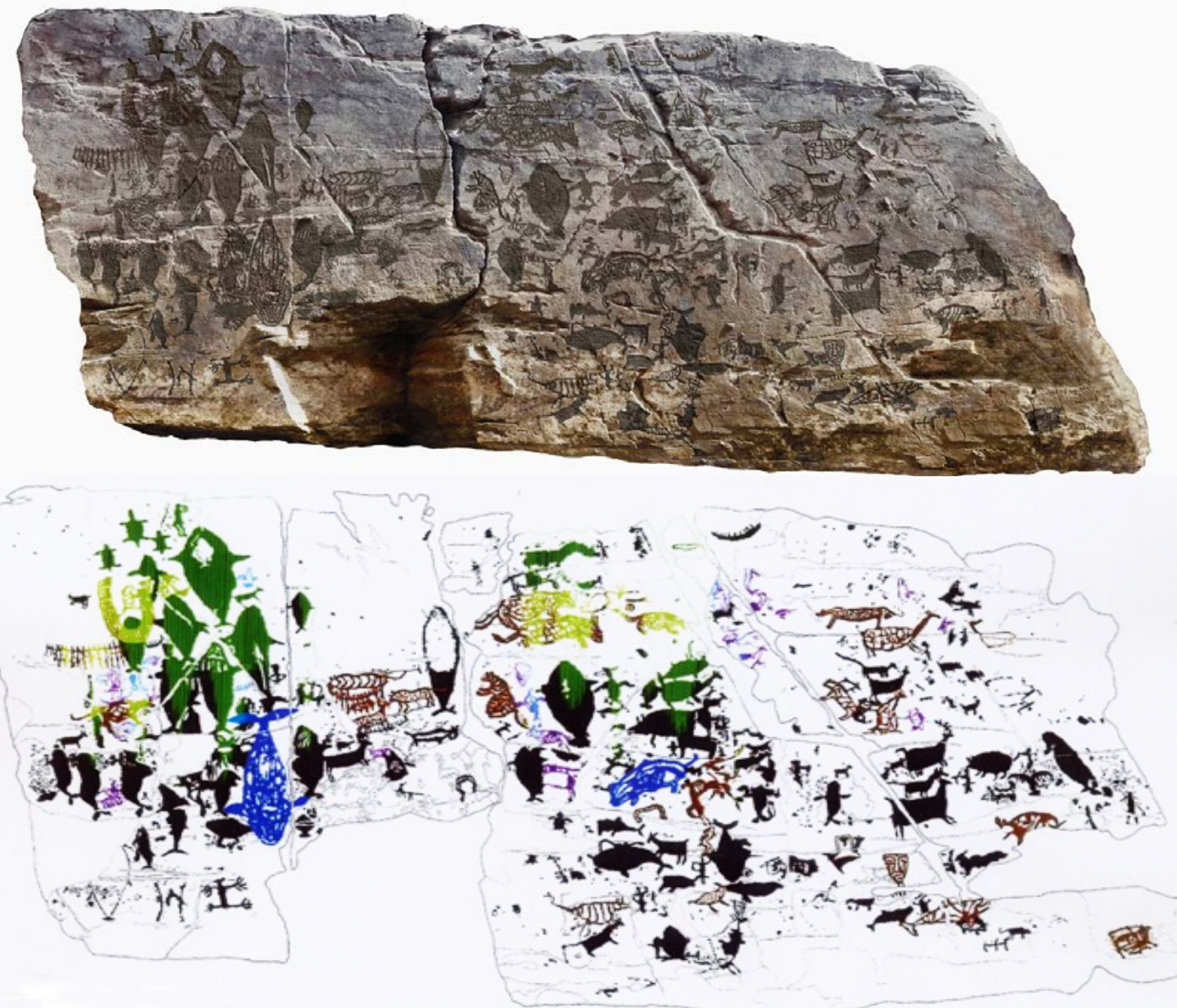

Figure 9. General view of Bangudae Petroglyphs [26]

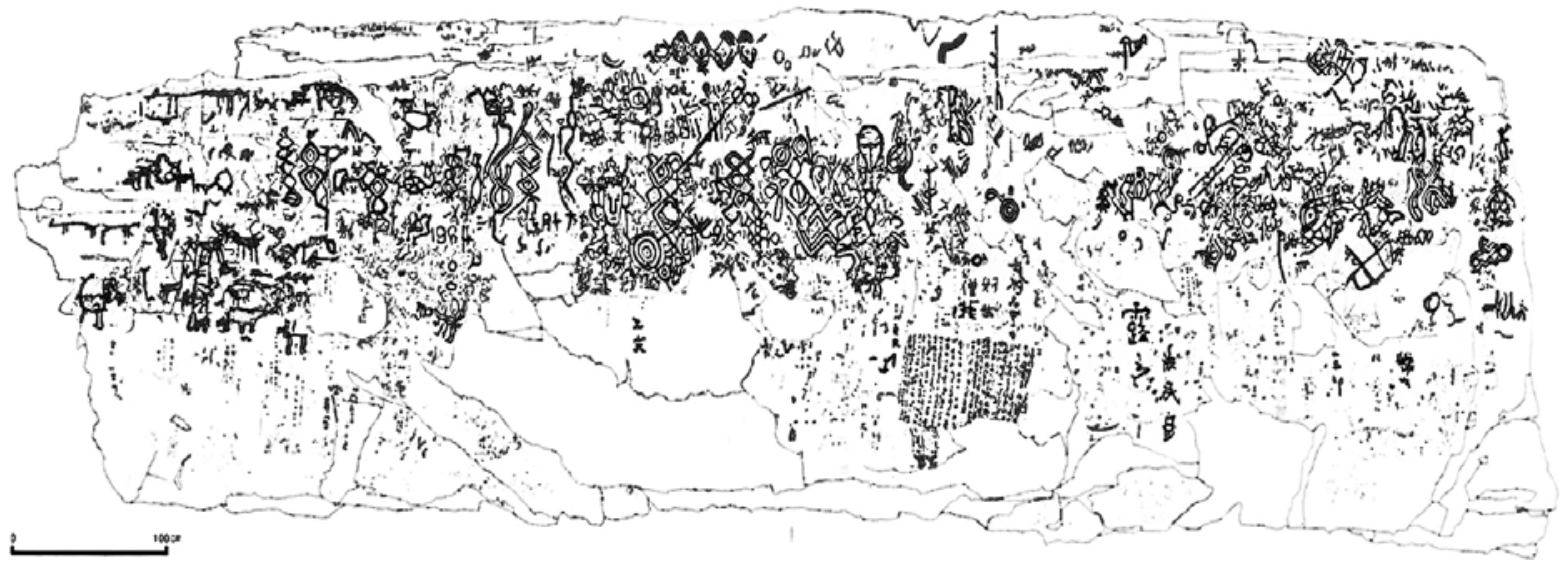

Figure 10. Drawing of Cheonjeon-ri Petroglyphs [25]

The Cheonjeon-ri petroglyphs are found on a rectangular panel $(2.8 \times 9.7$ meters $)$ and its surrounding rock surfaces. The Cheonjeon-ri petroglyphs' most unique feature is their overlapping images, which include animal and human figures from the late Neolithic or early Bronze Ages, geometric patterns presumably from the middle Bronze Age, line engravings of humans and animals from the Iron Age, and inscriptions from the Three Kingdoms Period 
and the Unified Silla Kingdom. The earliest engravings of animals and humans in the Cheonjeon-ri petroglyph, which are believed to have been influenced by Mongolian and Siberian cultures, are recognized as invaluable materials for the genealogy of prehistoric Korean culture. While the Bangudae petroglyphs are known for their images of sea animals, the Cheonjeon-ri rock carvings mostly consist of land animals, especially large-horned deer (Fig. 9). The geometric images of the Cheonjeon-ri petroglyph that are presumed to date back to the middle Bronze Age include many continuous overlapping lozenge patterns, concentric circles, spirals, and zigzags $[15,16]$. Although no clear explanations have been made of these images as they are very rare on the Korean Peninsula, similar geometric patterns have been discovered in the Mongolian Gobi, Siberia and northern China. This serves as evidence of the close relationship between the prehistoric cultures of Korea and Mongolia (Fig. 11, 12).

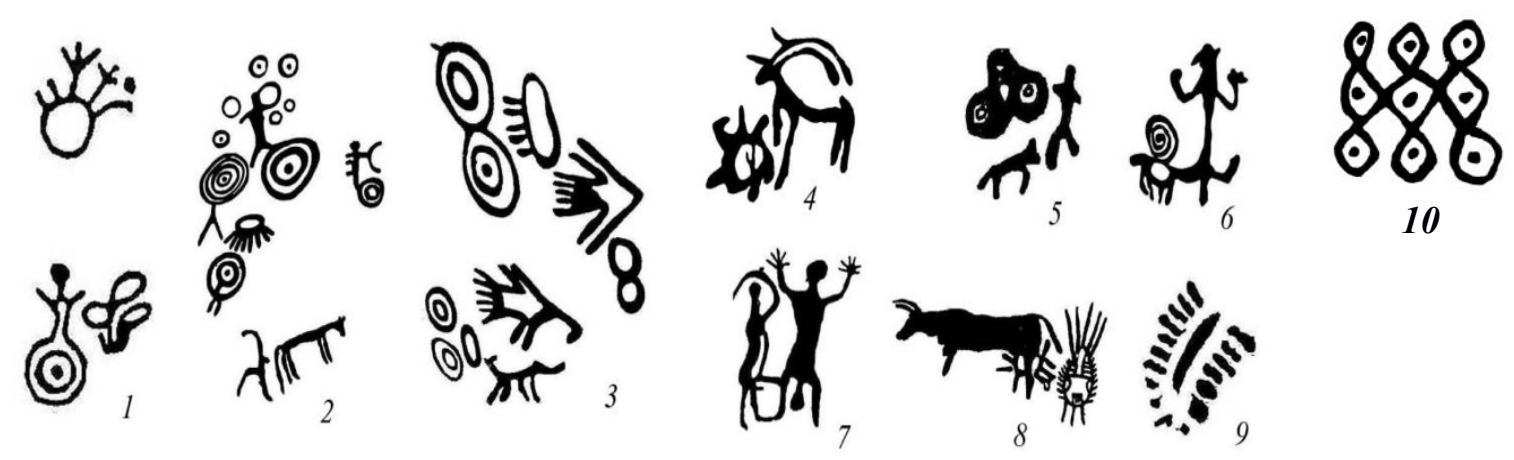

Figure 11. Some images of Mongolian Gobi petroglyphs: 1-3. Shuulengiin khudgiin bichees, Umnugobi; 4-5. Tevsh uul, Uvurkhangai; 6. Khavtsgait, Umnugobi; 7-8. Tsagaan dersnii Bichigtiin us, Umnugobi; 9. Bichigtiin am, Bayankhongor; 10. Dalain duulga, Umnugobi [18]

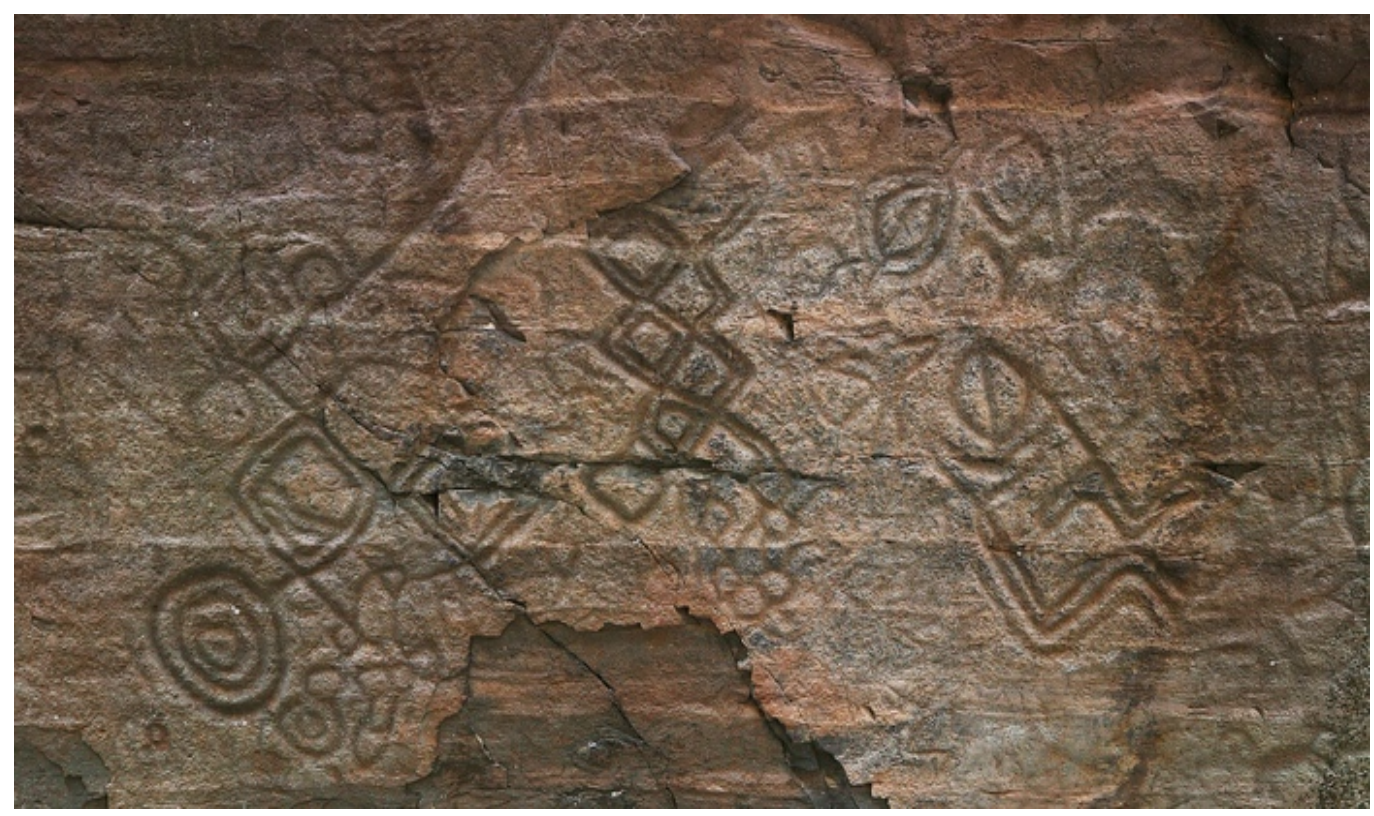

Figure 12. Detailed images of Cheonjeon-ri petroglyphs [26]

It has been some time since research into rock art started in Mongolia. As a result of an archaeological study conducted in Mongolia, more than 500 rock art sites have been identified and every year their number is increasing with new explorations. The rock art sites found all across the country are a valuable cultural heritage of humankind illustrating the stages of human development and history simultaneously. 
The Bangudae, Cheonjeon-ri and other petroglyph sites will be compared to the Petroglyphic Complexes of the Mongolian Altai (Tsagaan Salaa-Baga Oigor, Upper Tsagaan gol, Aral tolgoi) and a Petroglyphic Complex in the Mongolian Gobi (Del uul, Bichigtiin am, Javkhlant khairkhan). The Petroglyphic Complexes of the Mongolian Altai were registered in the World Heritage List in 2011 and Petroglyphic Complex of the Mongolian Gobi were registered in the World Heritage Tentative List in 2014.

Numerous rock carvings and funerary monuments found in these three sites illustrate the development of culture in the Mongolian Altai over a period of 12,000 years. The earliest images reflect the time $(11,000-6,000 \mathrm{BCE})$ when the area was partly forested and the valley provided habitat for hunters of large games. Later images show transition to herding as the dominant mode of life. The most recent images show the transition to a horse-dependent nomadic lifestyle during the early $1 \mathrm{st}$ millennium CE, the Scythian period and the later Turkic period (7th and 8th centuries $\mathrm{CE}$ ). The carvings contribute to our understanding of pre-historic communities in northern Asia (Fig. $13,14)$.

But these three complex sites of Mongolian Gobi are not only prominent evidence of the civilization and historical change of the North-eastern Asian nomads, but are also reflections of the culture, tradition, ritual, and art that had been developed and followed by them for hundreds of years, starting about 4000 years ago.

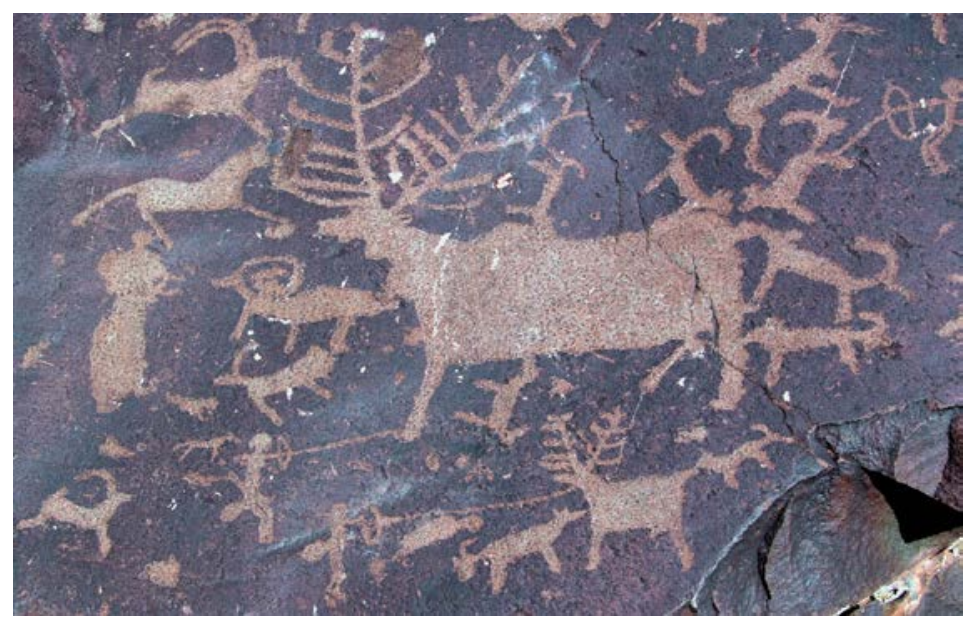

Figure 13. Hunting scene. Bronze Age, Upper Tsagaan gol, Mongolian Altai

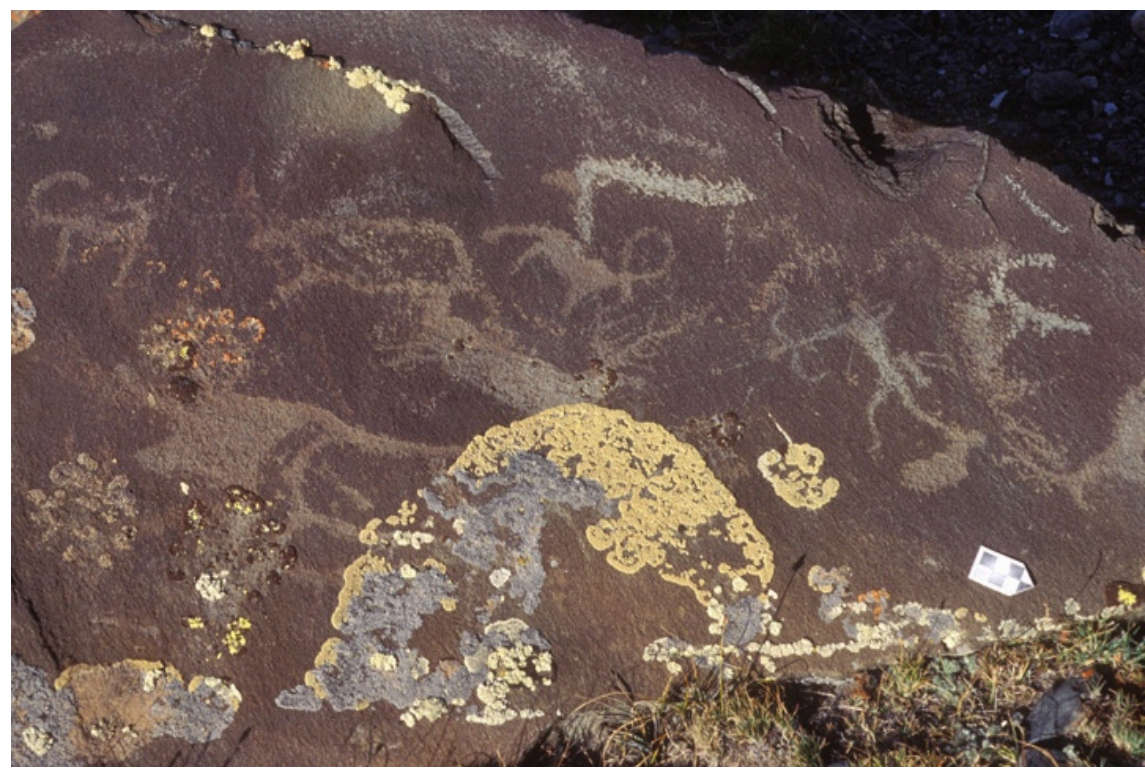

Figure 14. Hunter with re-curved bow, gorytus. Late Bronze Age, Tsagaan Salaa-Baga Oigor, Mongolian Altai [17] 
Human, mask, and animals. Some images of human, animals (deer, tigers, etc.) and hunting scenes of the Bangudae [13] are similar to the images of animal and hunting scenes of Mongolian Altai, Central Mongolia, and Mongolian Gobi petroglyphs [17, 18, 19]. But the depiction of mask is only similar to Mongolian Gobi petroglyphs [18] (Fig. 17). Therefore, images of dapple animals are similar to the images of predators on rock art, deer stones and some bronze objects (Fig. 15, 16).
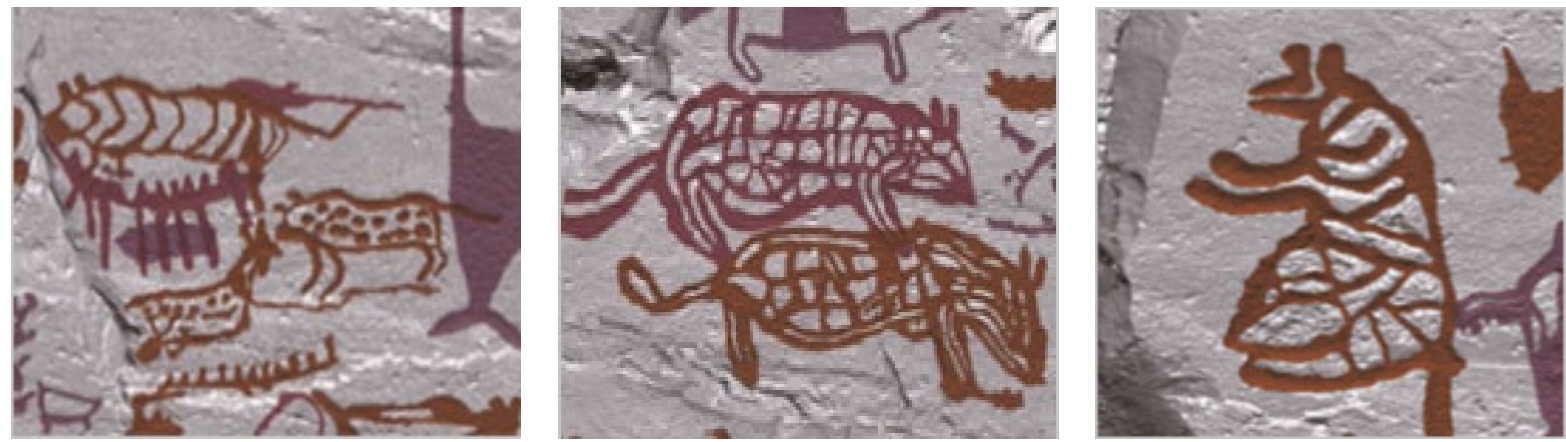

Figure 15. Depictions of predators of Bangudae Petroglyphs [26]
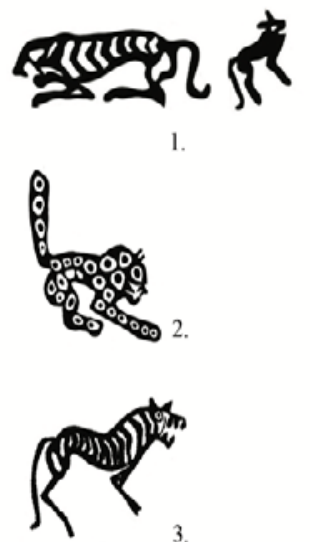

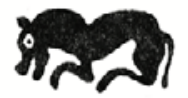

4.
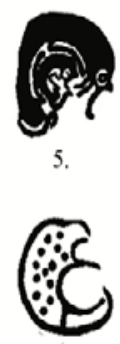
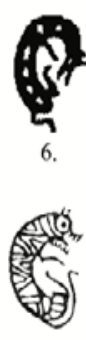
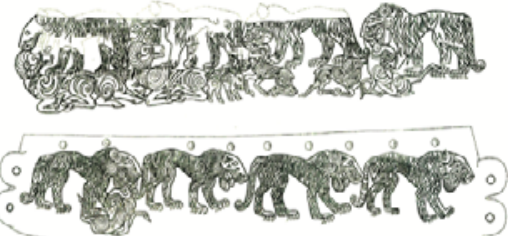

9.

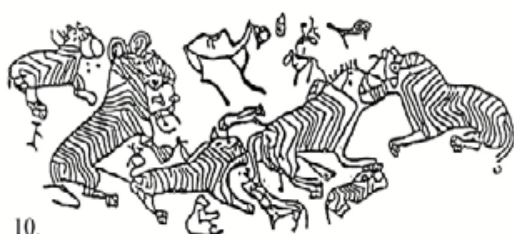

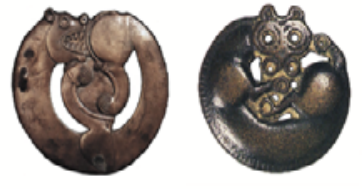

11.

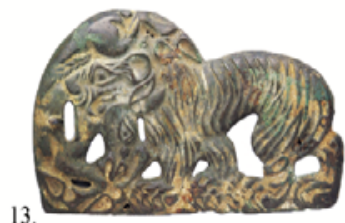

Figure 16. Some Images of predators on the rock art, deer stones, and wooden coffin and bronze object: 1-8. Deer stone; 9. Wooden coffin; 10. Rock art; 11-13. Bronze objects

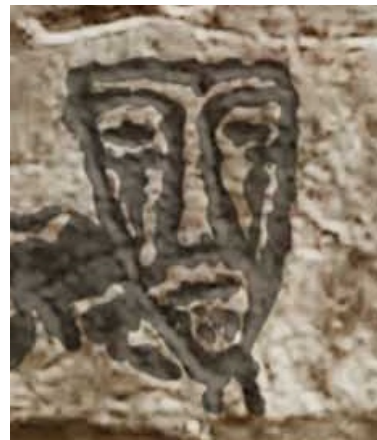

Mask of Bangudae

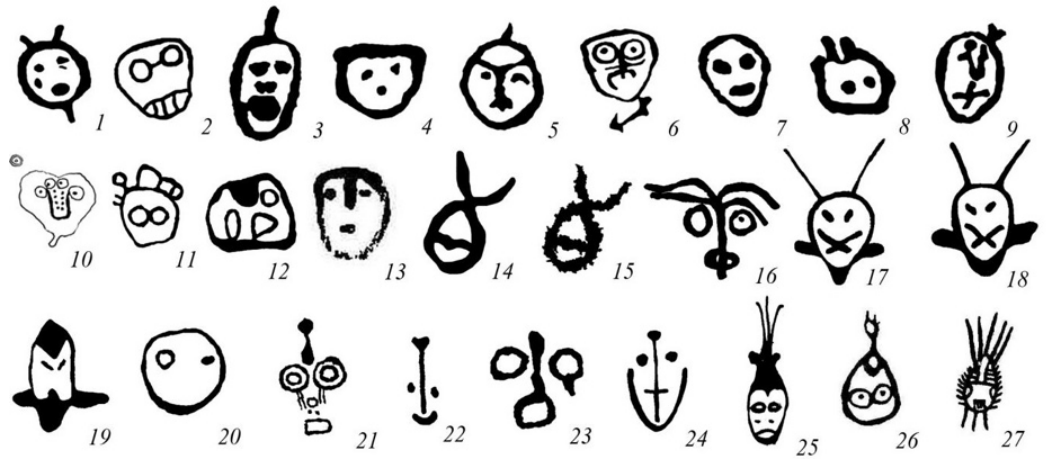

1-10. Zuun Khatsavch, Umnugobi; 11-12. Dalain duulga, Umnugobi;

13. Ikher gashuun, Umnugobi; 14-15. Togoo khairkhan, Umnugobi; 16-24. Javkhlant khairkhan, Umnugobi; 25. Tsagaan bukhtyn gol,

Umnugobi; 26. Shuulengiin khudgiin bichees, Umnugobi; 27.

Tsagaan dersnii Bichigtiin us [18]

Figure 17. Masks of Bangudae and Mongolian Gobi petroglyphs 
Geometric image. In addition, some depictions of geometric lines of Cheonjeon-ri petroglyphs are similar to depictions of some images of Mongolian Gobi petroglyphs. However, the dimension of images of
Cheonjeon-ri petroglyphs is large and carved is depth [15, 16], whereas the images of Petroglyphs of Mongolian Gobi are small and the carvings of of little depth [18] (Fig. 18, 19).

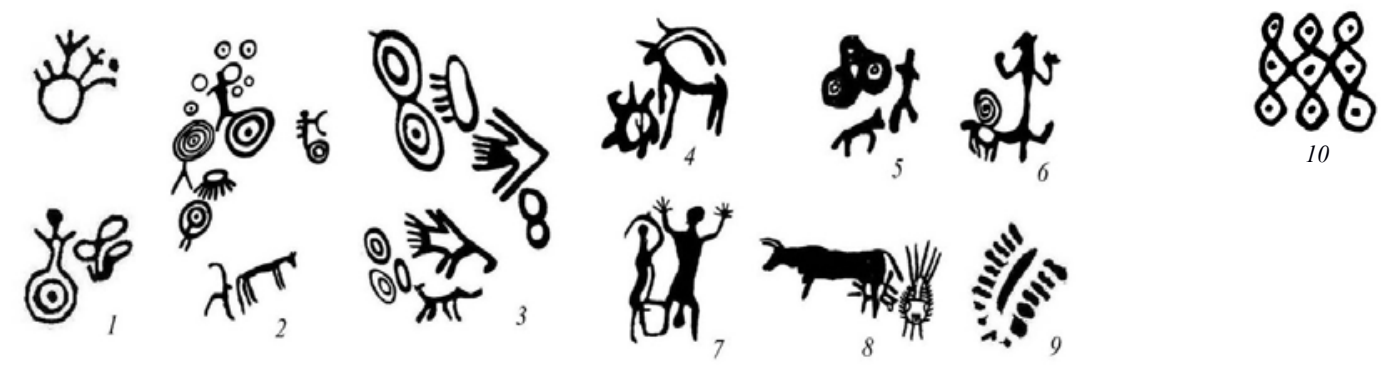

Figure 18. Some images of Mongolian Gobi petroglyphs: 1-3. Shuulengiin khudgiin bichees, Umnugobi; 4-5. Tevsh uul, Uvurkhangai; 6. Khavtsgait, Umnugobi; 7-8. Tsagaan dersnii Bichigtiin us, Umnugobi; 9. Bichigtiin am, Bayankhongor; 10. Dalain duulga, Umnugobi [18]

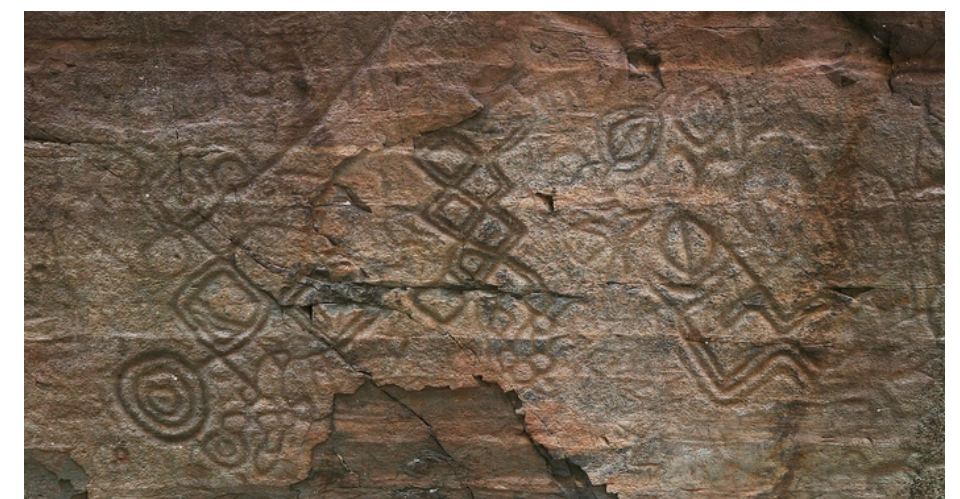

Figure 19. Detailed images of Cheonjeon-ri petroglyphs [26]

Spiral image. Spirals are common in the petroglyphs of Europe, America, and Central Asia. Researchers explain the semantic of the spiral in many ways. Big stone plate and menhir with spiral images are located in Dohang-ri site, Haman, Bokcheon-dong, Busan, Anin-ri, Milyang, Gyeongnam, Jincheon-dong, Cheonnae-ri, Daegu, Yangjeon-dong,
Goryeong, Gyeongbuk of Korea [11] (Fig. 20). However, spiral images are rarely found among the petroglyphs of Mongolia, but such spiral images are engraved on numerous deer stones of Mongolia (Fig. 21). Researchers describe spiral images engraved under the neck of the deer stones which explain they are an object [20].

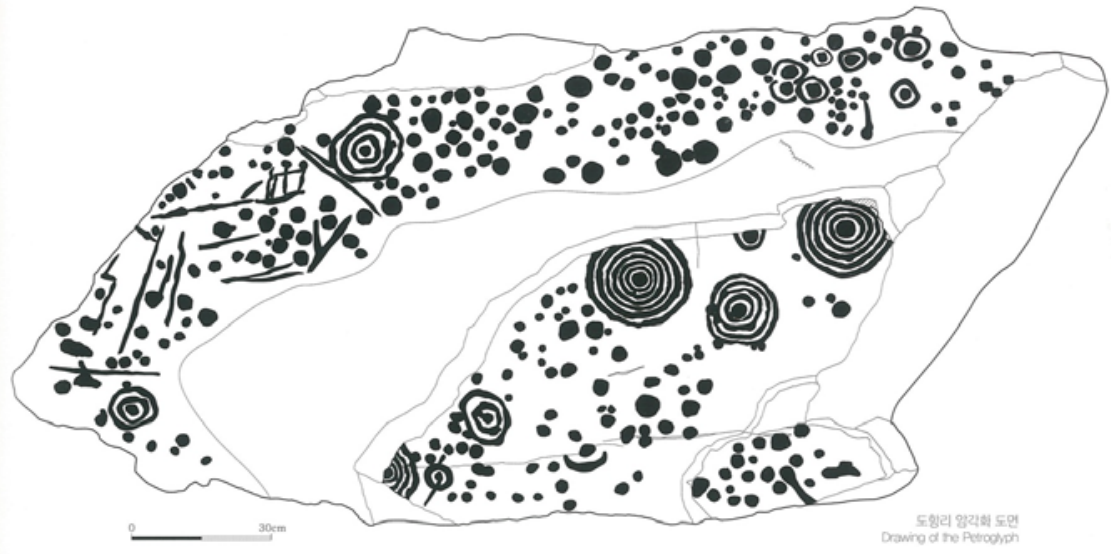

Figure 20. Spirals on the rock of Dohang-ri, Haman, Busan [11] 

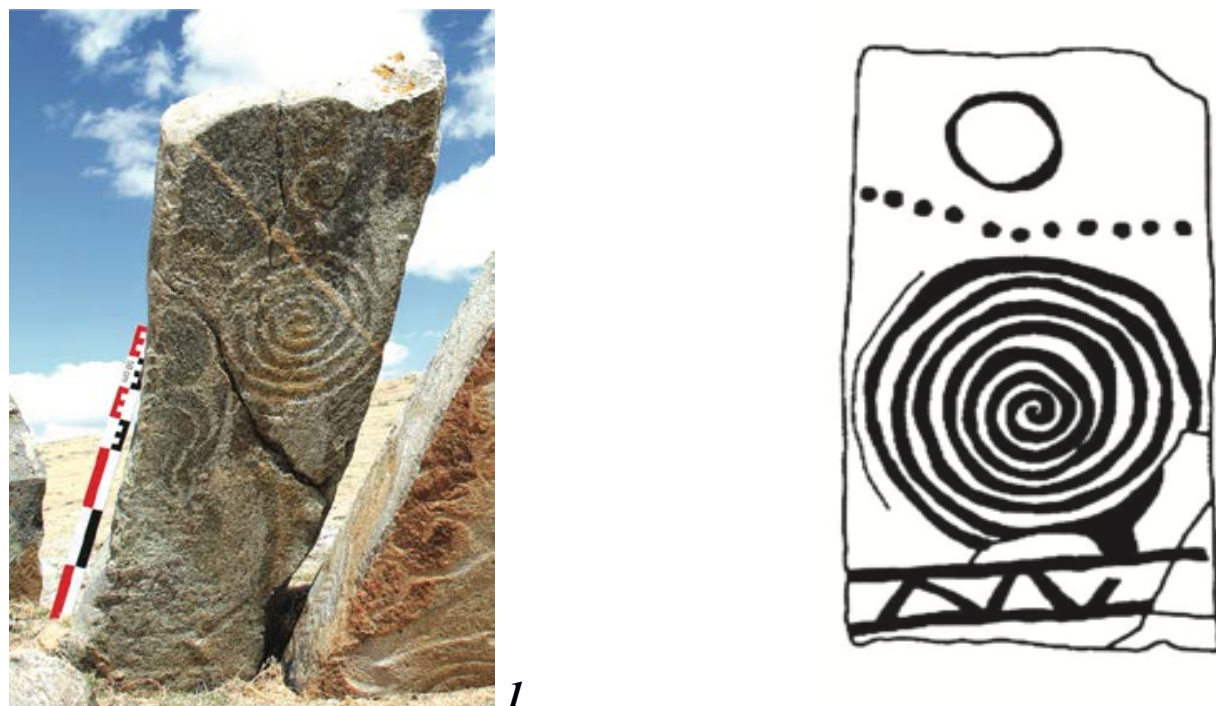

Figure 21. Spirals on the Deer stones, Mongolia:

Zuun Shivertiin am, Undur-Ulaan, Arkhangai, 2. Khurtelgiin am, Zuunkhangai, Uvs [20]

Incised image. Incised images of Ungokdong of Naju, Cheonnam are most interesting. The figuration was mainly pictures of fine lines in mesh type. 54 pieces in points on the rocks were found. The prehistoric petroglyph found till now were mostly engraved with the skills of picking, grinding and turned picking. It seemed that the figuration, which was difficult to read due to wearing and overlapping, would almost be of the same shape [11] (Fig. 22). Similar depictions were found in some petroglyph sites of Mongolia. Incised images of Khuruugiin uzuur in Central Mongolia can be named here, which dates to the Early Bronze Age, about 5000 years ago. These incised images of Khuruugiin uzuur can be described as related to rituals [19] (Fig. 23)

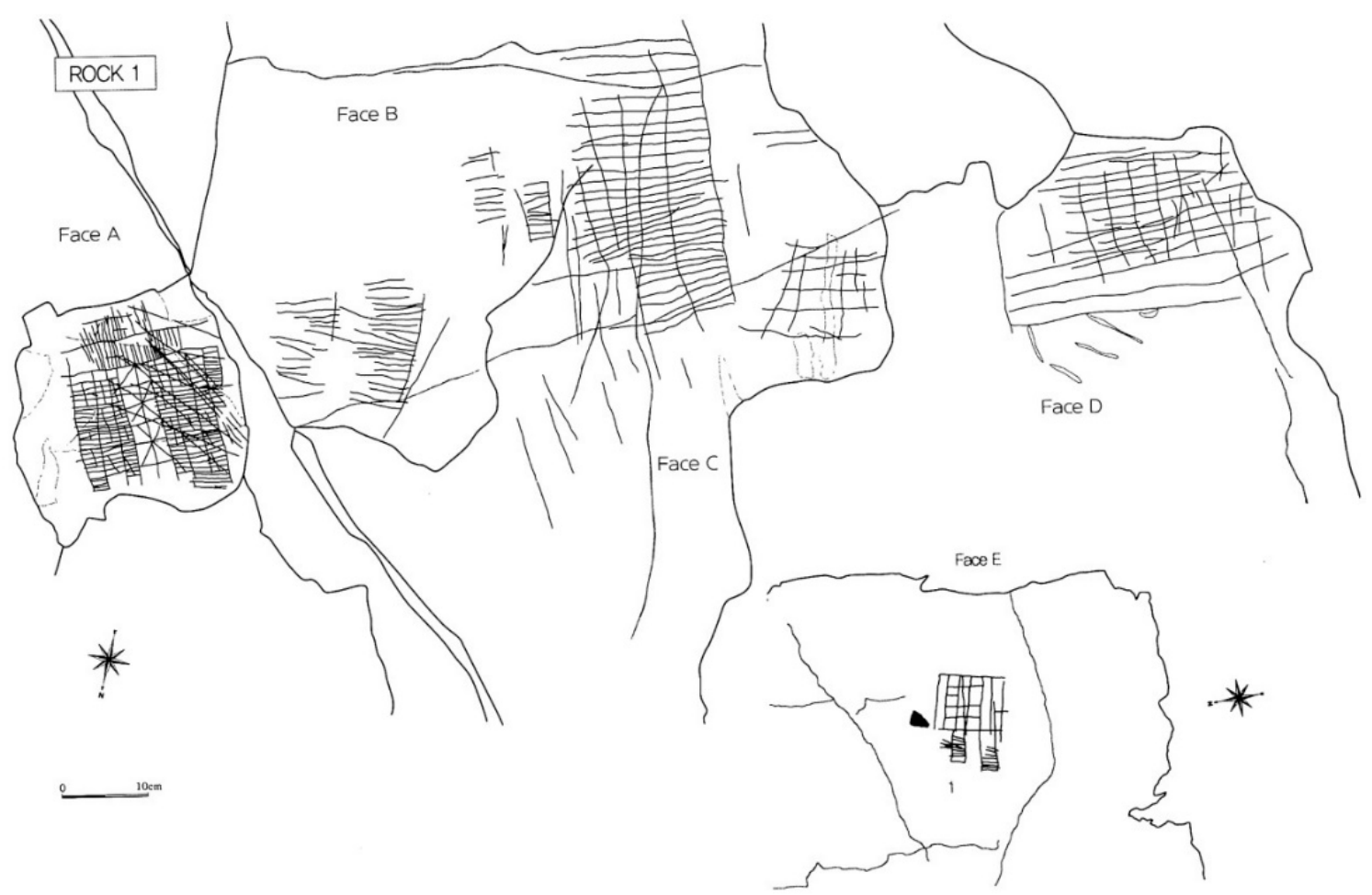

Figure 22. Some incised images of petroglyphs, Ungok-dong, Naju, Cheonnam [11] 


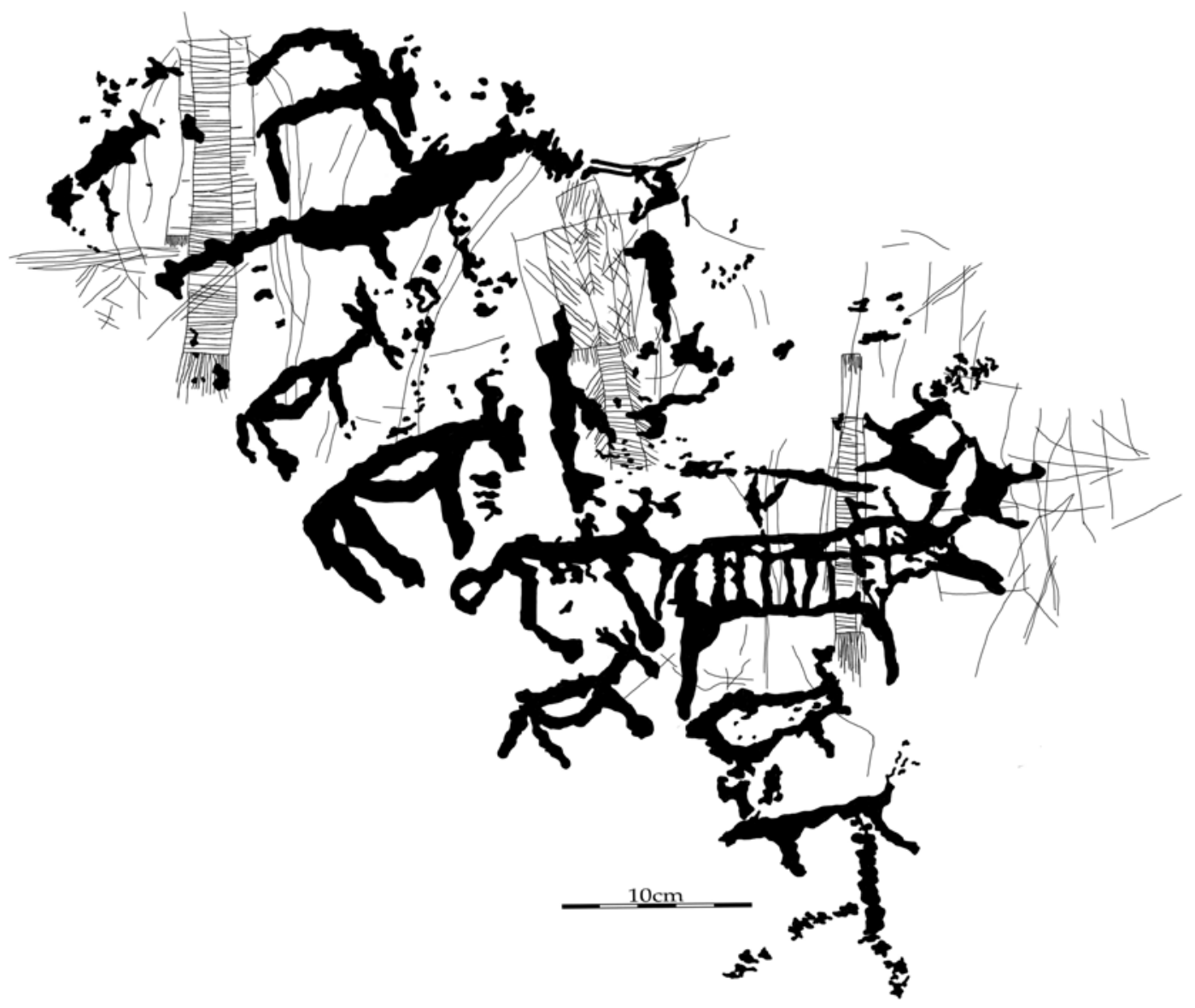

Figure 23. Some incised images of petroglyphs, Khuruugiin uzuur, Arkhangai, Mongolia [19, 28]

Tamga / seal. A marking with branding iron (tamga) is a historical source and a cultural heritage of the ancient nomads. They contain valuable information about their origins and ancestors. The roots of the markings (tamgas) date back to the prehistoric period, the matriarchal society, when the ancient people used seals (tamgas) to differentiate their tools and other property or inform others of later generations of that ownership - especially when exchange and the division of labor started to increase and solidify. The tradition of depicting the marking (tamga) and its impression on rock panels was a common practice in the neighboring countries of Asia, Europe, Africa and even in North America. The images illustrating markings, created in the Bronze Age, generally, are divided into two groups, namely tribal marking (tamgas) and hoof (footprints or tracks of animals) markings. Some simple animal tracks were used as markings (tamgas) in the period of clan societies, which later formed the basis for the further development of the seal design [21] (Fig. 24). The tribal and hoof markings (tamgas) are common in petroglyphs of Mongolia.

We found some interesting images that appear like hoof markings (footprints or tracks of animals) from ancient Korean rock art, especially in Sugok-ri of Andong and Seokjang-dong of Gyeongju, Gyeongbuk. But Korean researchers regarded double $\cap$ shaped seals of Sugk-ri, Andong - the pattern of the sexual organ of female for reflecting the agricultural farming society, which emphasized the power of birthing by women [11] (Fig. 25). 

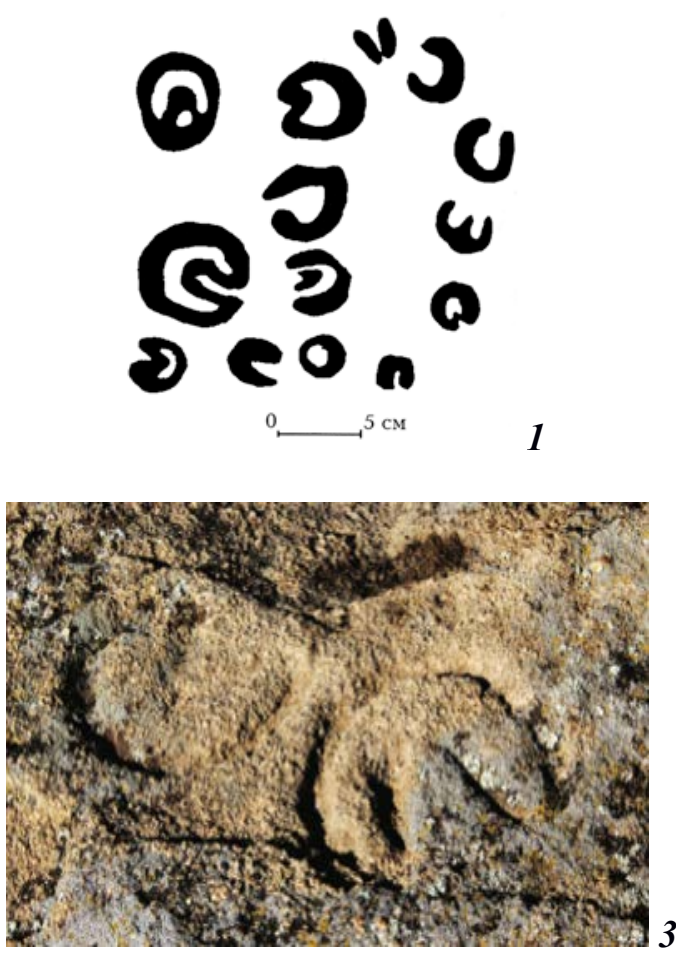
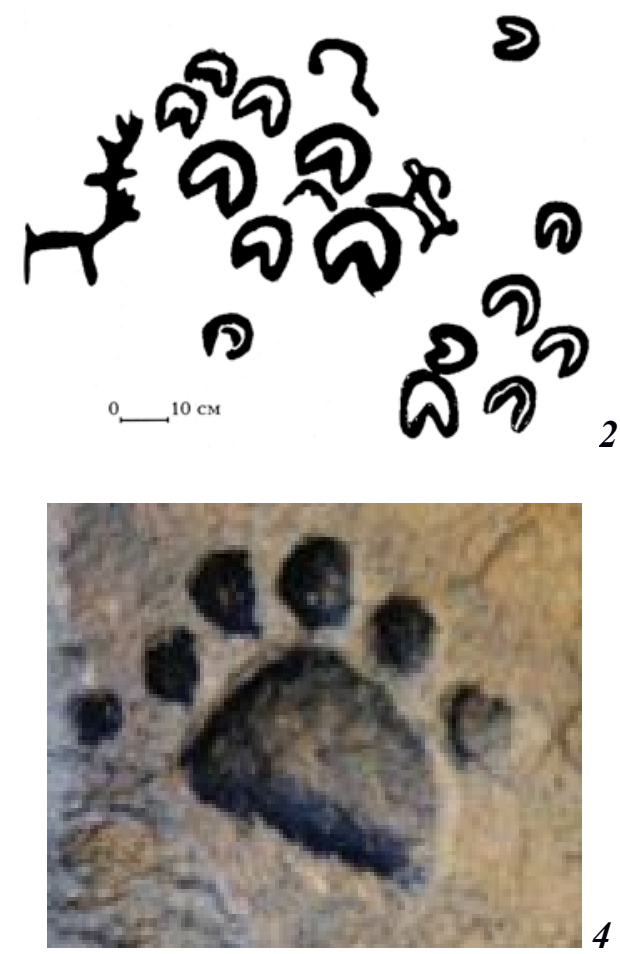

Figure 24. Some hoof seals of Mongolian petroglyphs:

1. Khar Tsagaan us, Zuungobi, Uvs; 2. Tsakhiriin khad, Tsetserleg, Khuvsgul; 3, 4. Uzuur tsokhio, Batshireet, Khentii [21, 29]
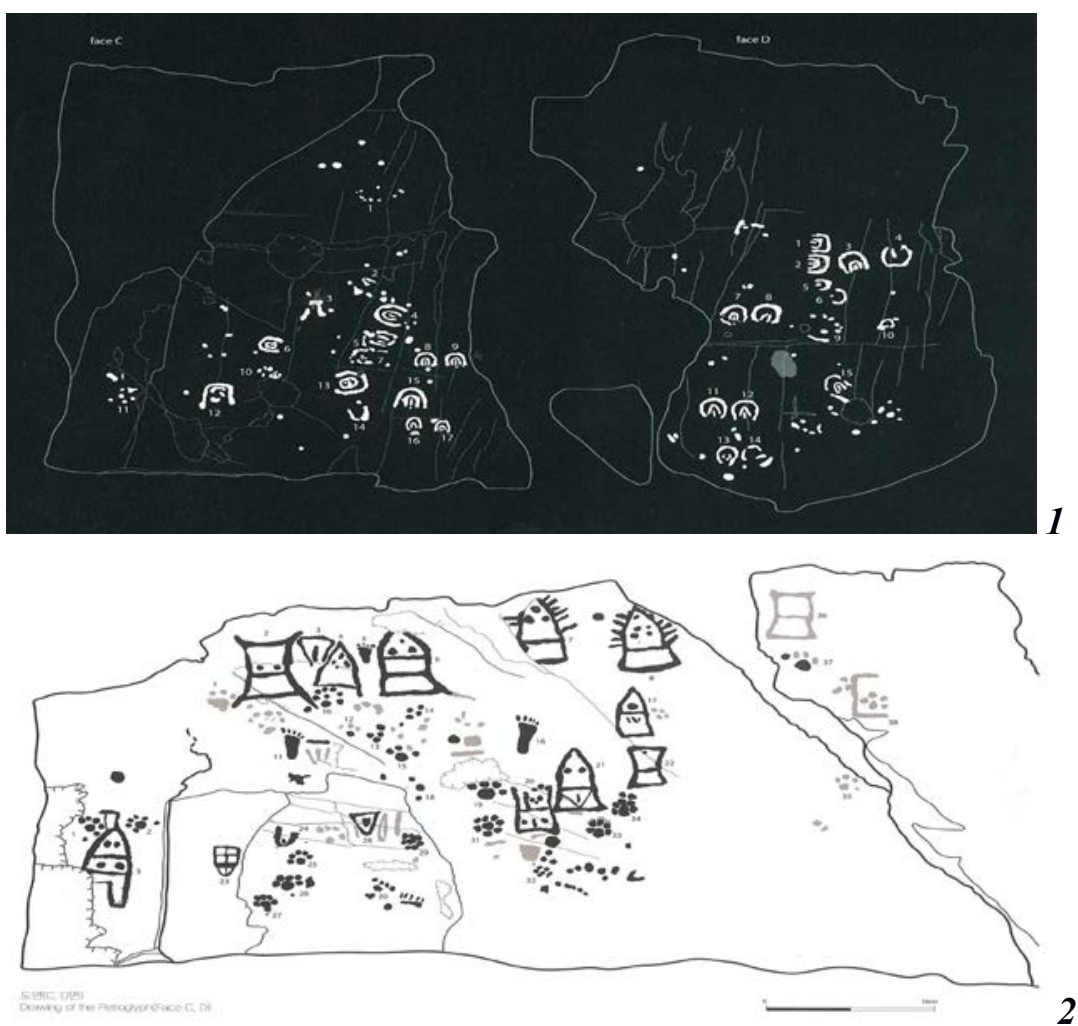

Figure 25. Some hoof seals of Korean petroglyphs:

1. Sugok-ri, Andong; 2. Seokjang-dong, Gyeongju, Gyeongbuk [11] 


\section{Comparison of artifacts}

The comparison of artefacts is another part of the comparative study. There are so many different kinds of artefacts that can be compared. Some of them have similar shape and belong to the same period, some belong to the same period and are of identicial shape but are made of different materials, or some of them have a similar form but belong to a different period. For example:

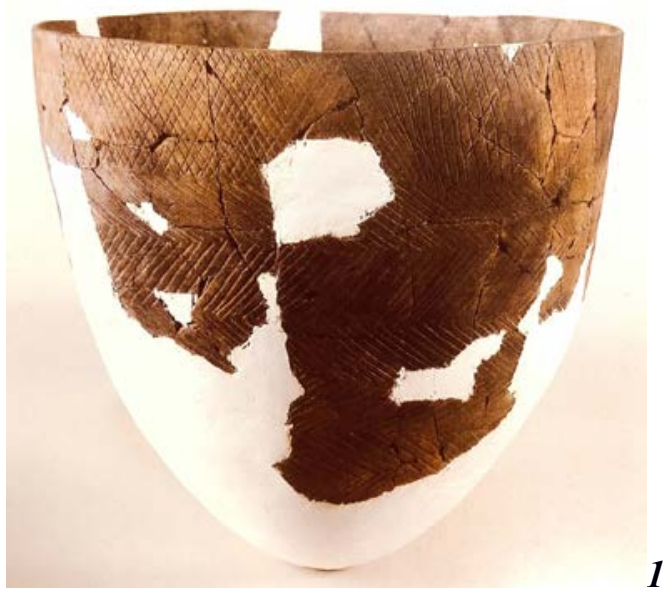

1. Pottery. Potteries of Neolithic Age, with egg-shaped bottoms, are similar and appertain approximately to the same period, but the difference is some of them have neck, while others do nto have neck (Fig. 26. 1, 2). But shards of pottery with comb-pattern of Songguk-ri site and other site are exactly similar to the shards of pottery with comb-pattern of Early and Late Bronze Age of Mongolia.

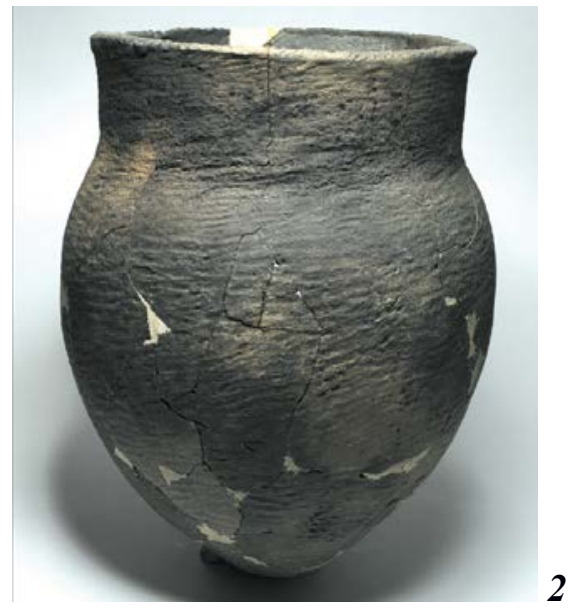

Figure 26. 1. Comb-pattern pottery, Osan-ni, Korea [30]; 2. Egg-shaped bottom pot (chance finding), Mongolia [31]

2. Pottery. For potteries of Chandmani-Sagil, Pazyryk culture and Songguk-ri site are different from each other in terms of shape, design, and color, but they have the same function. Furthermore, potteries of pit- houses of Hanan Misa-ri, Jecheon Hwang Sok-ri, and Jinju Sangchon-ri sites are typically similar to ceramics of slab graves of Mongolia with their shape and decoration (Fig. 27-30).

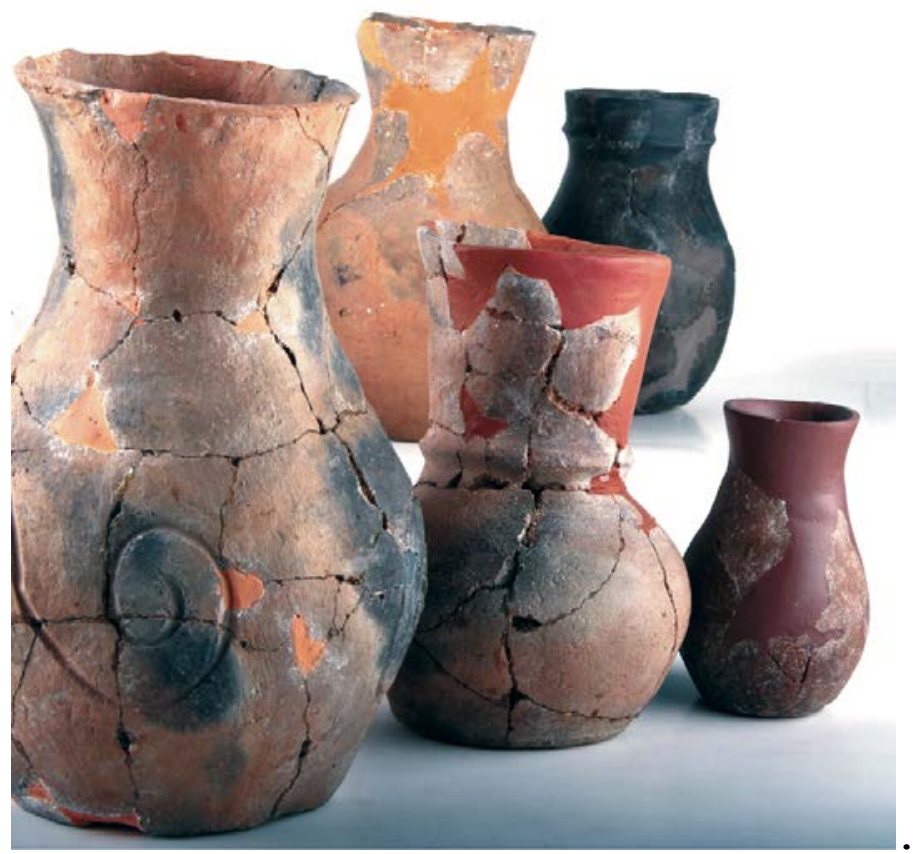

Figure 27. 1, 2. Potteries of Chandmani-Sagil and Pazyryk culture, Mongolia [32] 


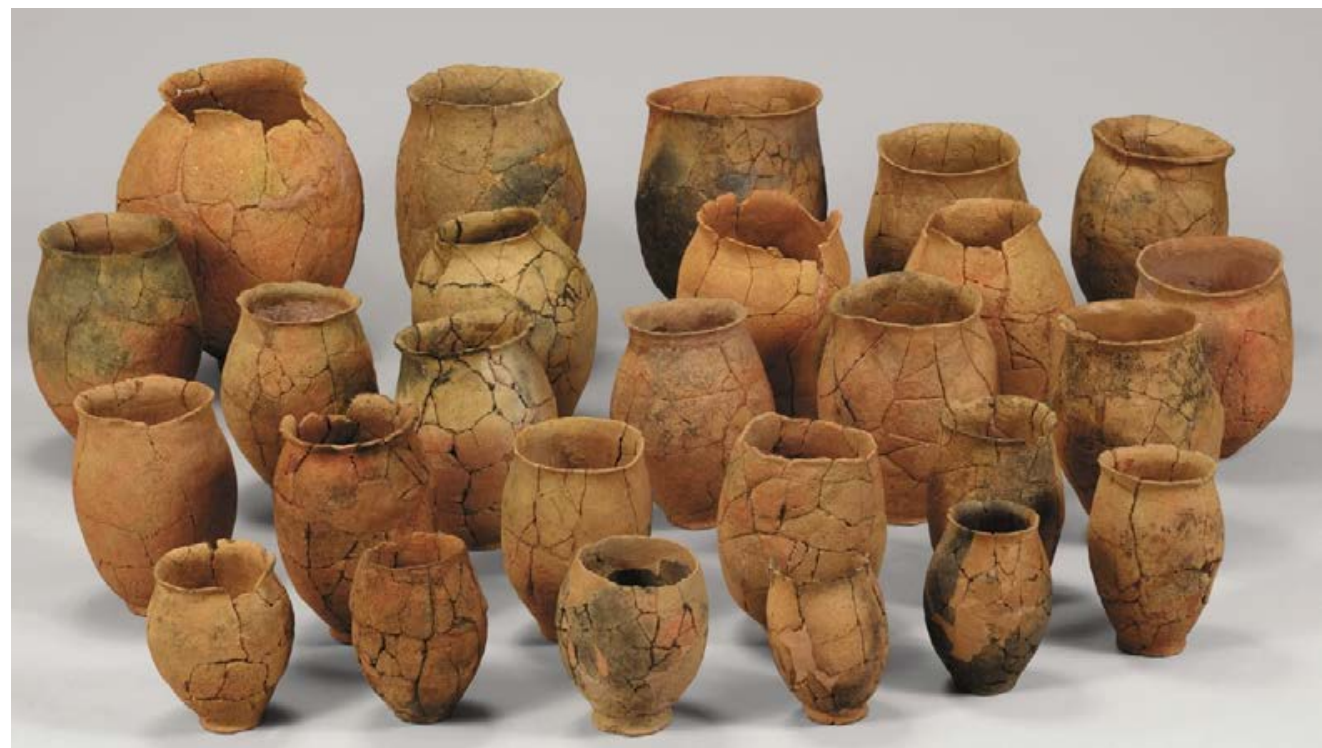

Figure 28. Potteries of Songguk-ri site, Buyeo [27]
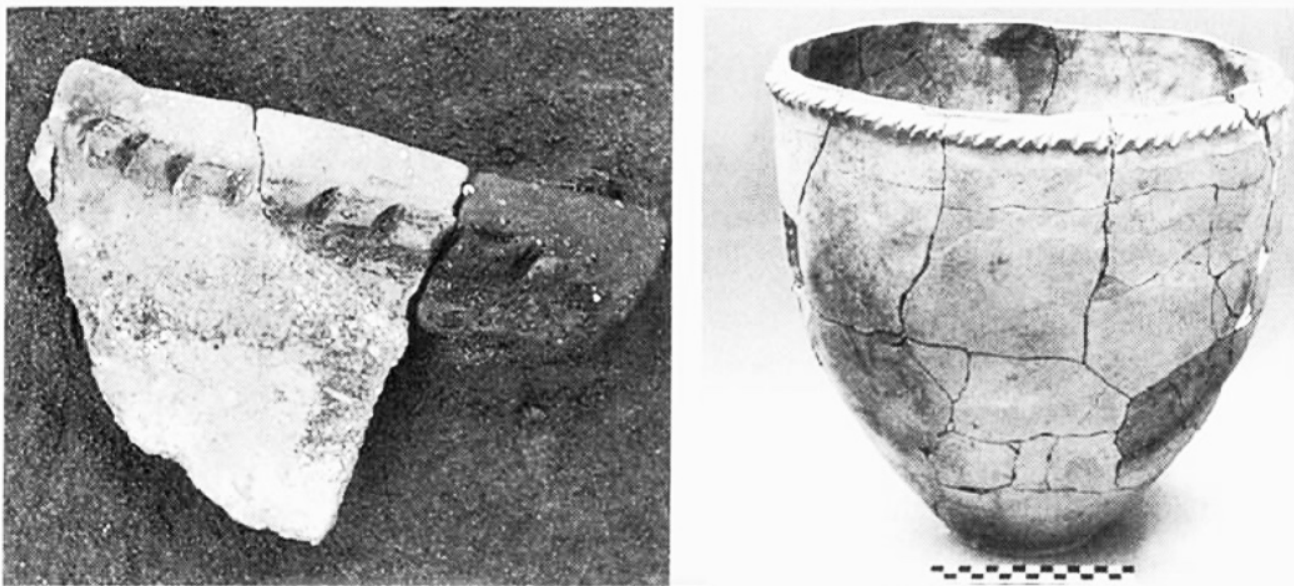

Figure 29. Potteries of pit-houses: Jecheon Hwang Sok-ri and Jinju Sangchon-ri [25]

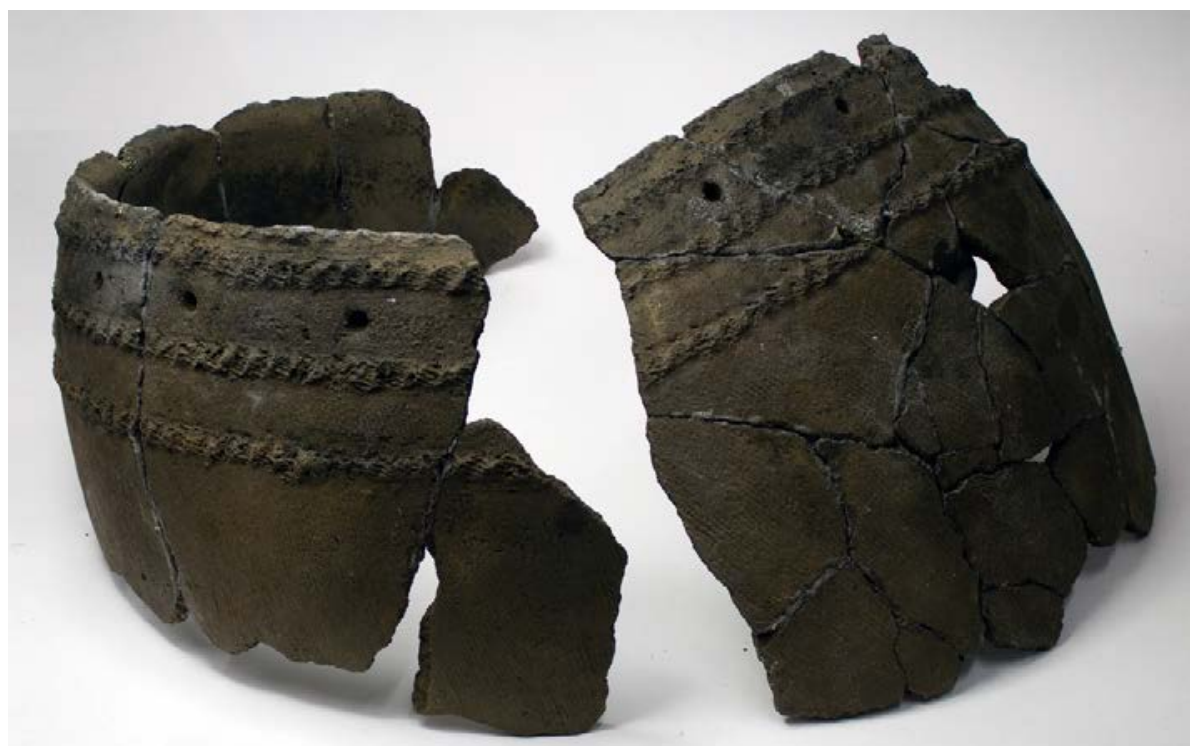

Figure 30. Pottery of Slab grave, Narst, Bulgan, Northern Mongolia [32] 
3. Arrowheads. These are artefacts that have been found from graves of all periods under consideration. From the Neolithic Age to Medieval period, and made from many different materials (stone, bronze, iron, antler, and wood). From Korea mostly stone arrowheads are known, but from
Mongolia, arrowheads are mostly made of metals and antler bones. Interestingly, some bone arrowheads of Slab graves are very similar to the stone arrowheads of Songguk-ri site, Majeon-ri site and Dolmens (Fig. 31, 32).
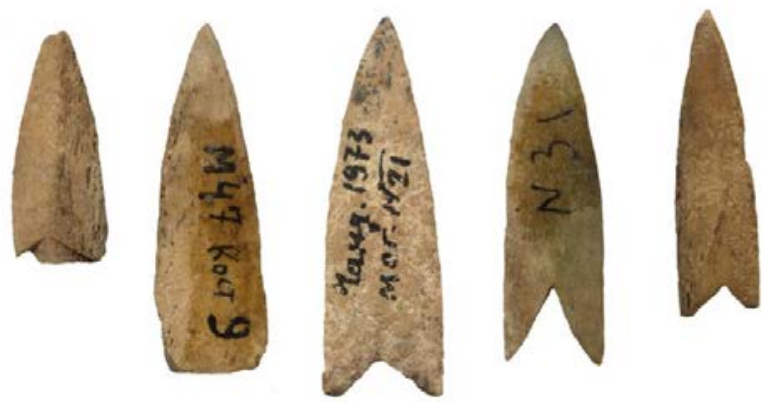
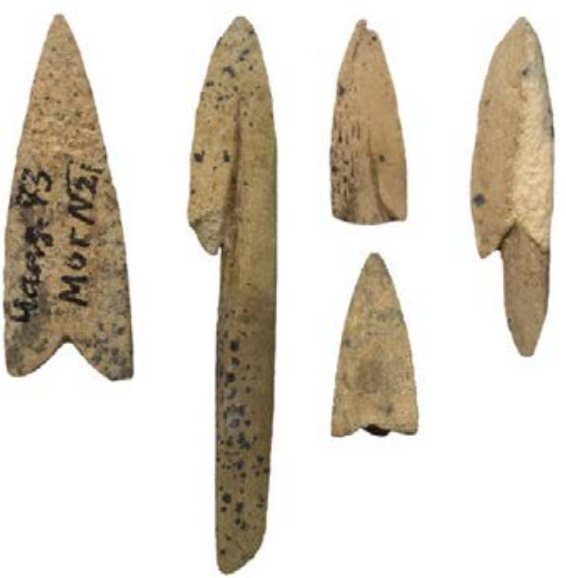

Figure 31. Bone arrowheads of Chandmani-Sagil culture, Western Mongolia [33]
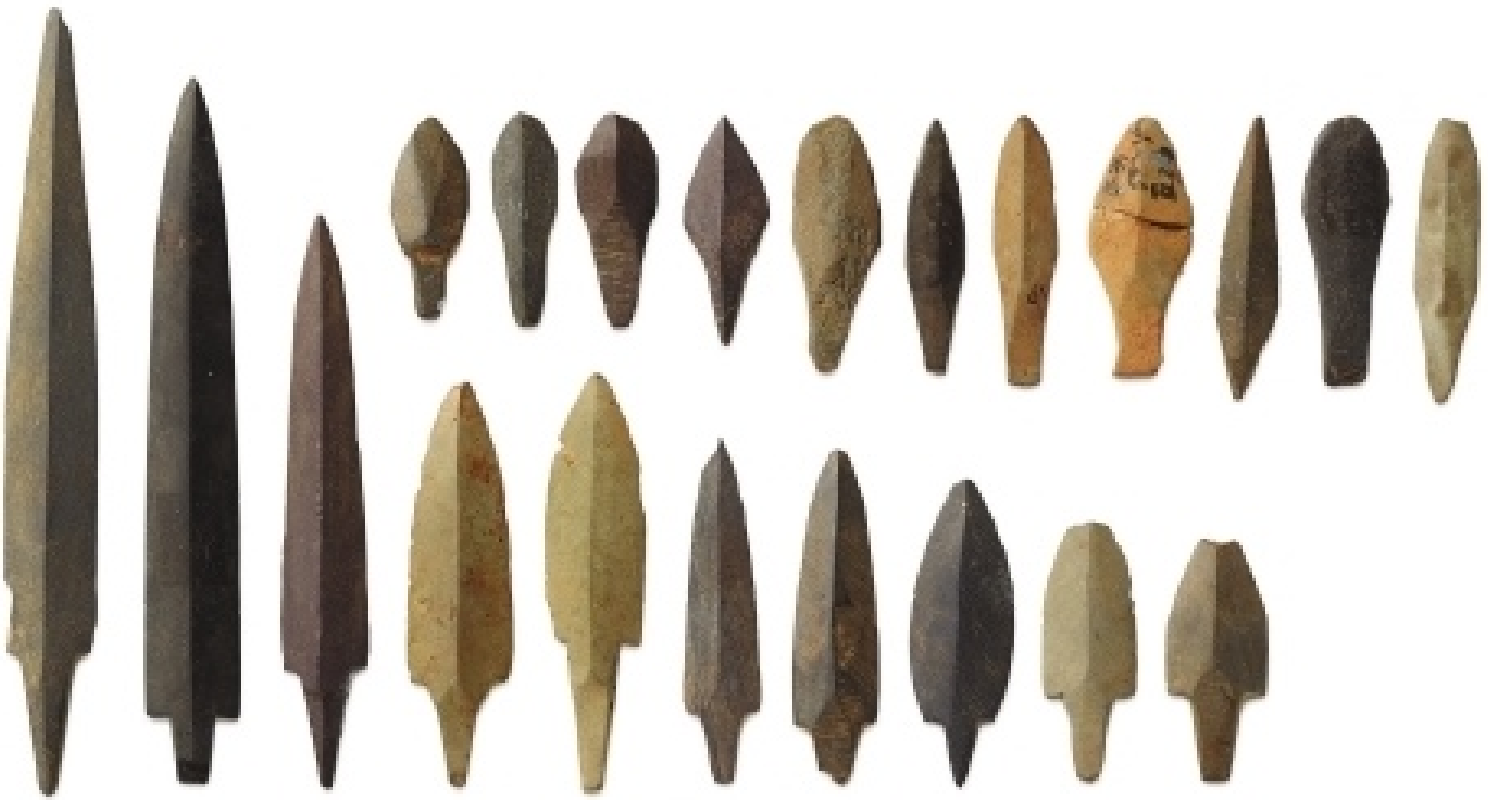

Figure 32. Stone arrowheads of Songguk-ri, Buyeo and Majeon-ri, Nonsan [27]

4. Daggers. As regards daggers, Korean and Mongolian daggers are totally different from each other in terms of their shape (form), design and materials used. One of the characteristics of the Korean's polished groundstone daggers are that they are mostly well preserved as compared to the Mongolian ones. Mongolian daggers are mostly made of bronze and iron (Fig. 33,
34). Although the main function of groundstone daggers is unknown, they have been implicitly linked with authority and leadership, and some have asserted that they were "... intended for ceremonial or symbolic use" [22]. But the origin of the shape of groundstone daggers is a matter of debate. They have been compared with short bronze swords of the Western Zhou 
to Warring States Periods (c. 1045-256

$\mathrm{BCE}$ ) in China. Russian scientist A. P. Okladnikov and others have suggested that the cultural and technological influence that account for groundstone daggers in Korea and Japan came from Karasuk and Tagar bronze cultures [22].
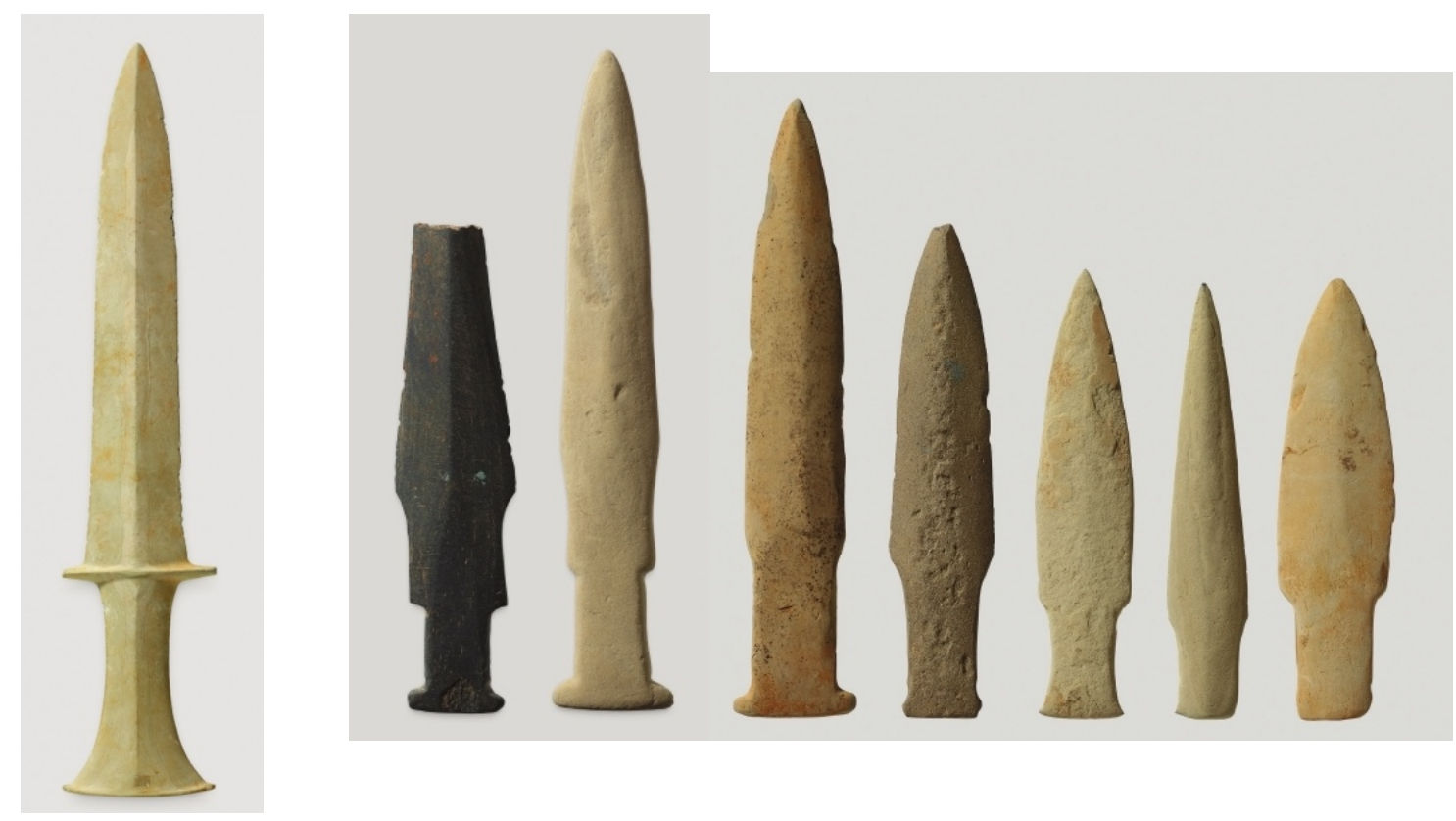

Figure 33. Polished stone daggers, Songguk-ri, Buyeo [27]
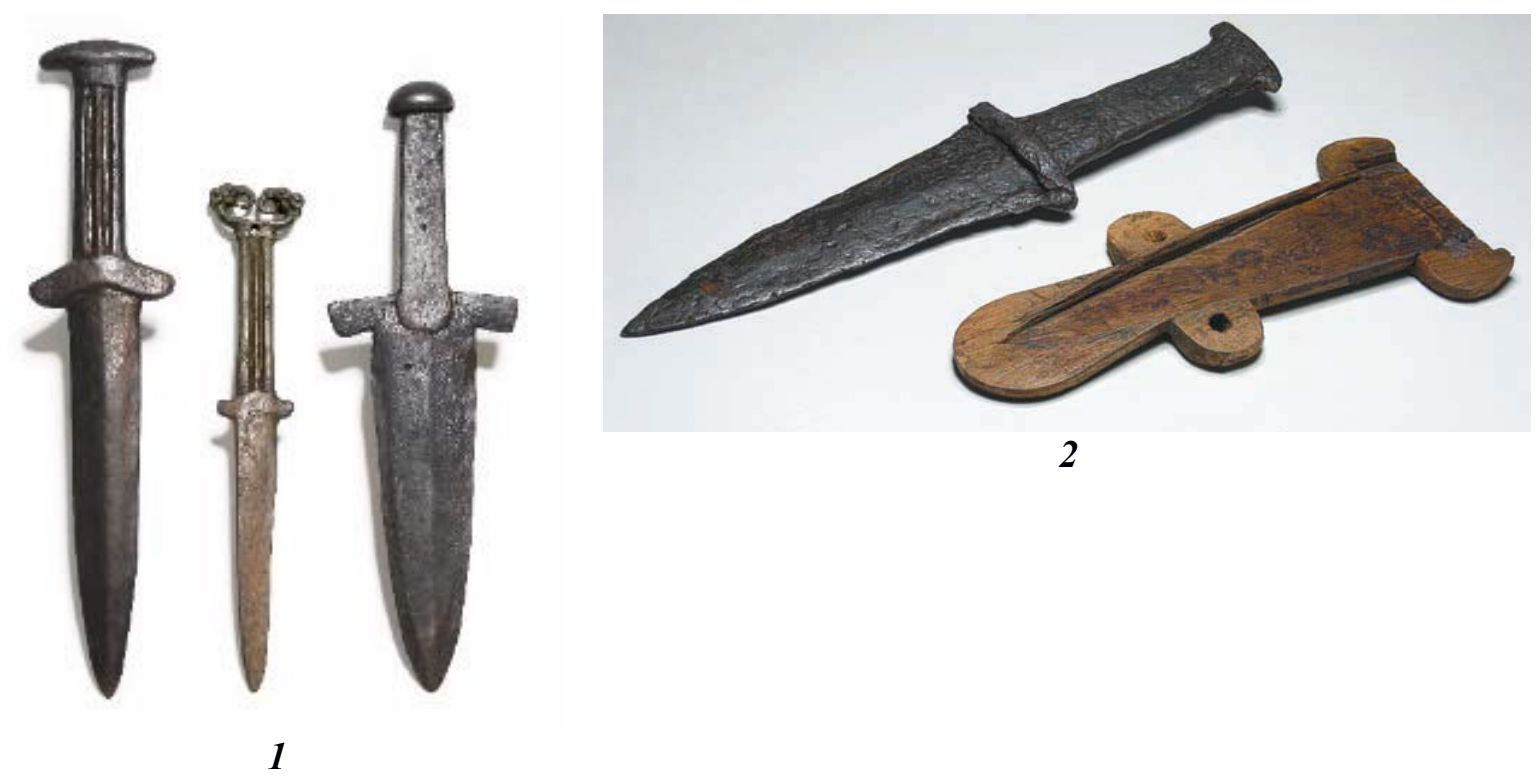

Figure 34. Bronze daggers of Chandmani-Sagil and Pazyryk cultures, Western Mongolia

5. Mirrors. The bronze mirrors of Chandmani-Sagil culture and Dongseo-ri ruins, with circular shapes, are similar and belong to approximately the same period. Their difference is in the handles, as a big handle on the edge of a mirror is typical for the Chandmani-Sagil culture and a small handle on one side of the mirrors is characteristic of the Dongseo-ri ruins (Fig. 35). But they may be similar in terms of ritual practices in graves. 

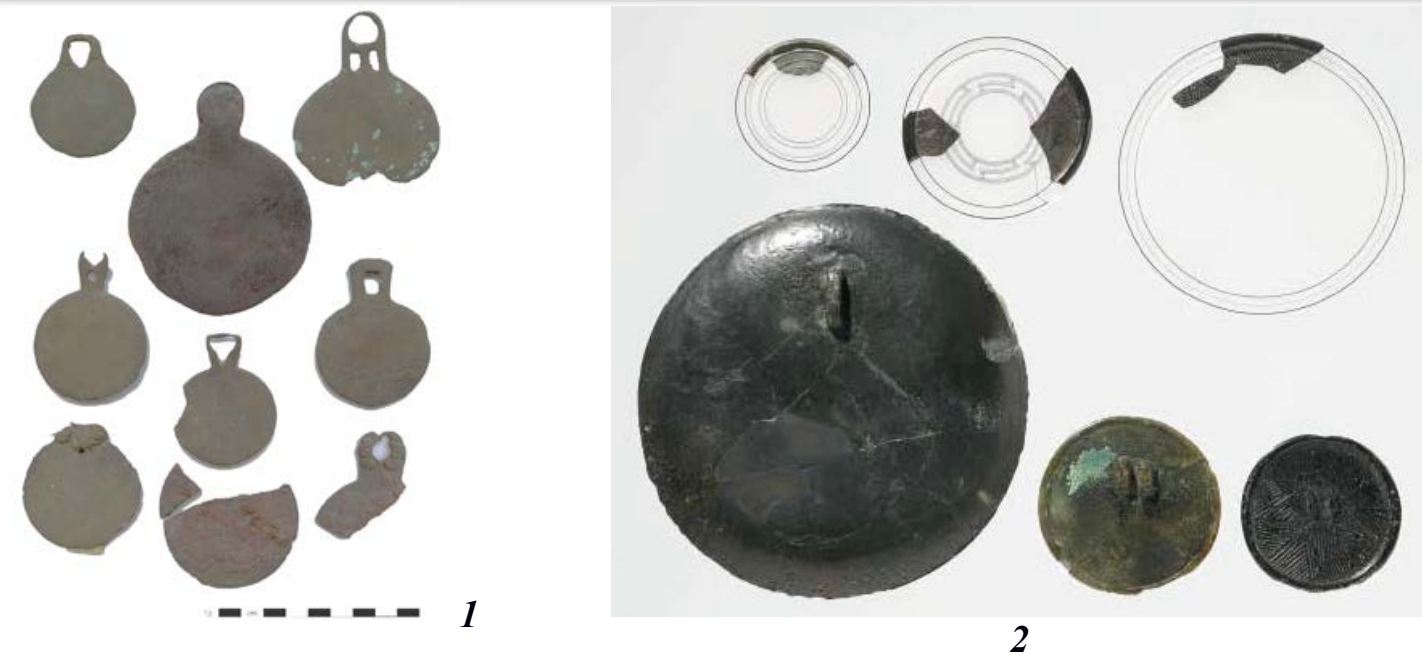

Figure 35. Bronze mirrors: 1. Chandmani-Sagil culture, Western Mongolia [33];

\section{Dongseo-ri ruins [27]}

6. Beads. For beads, Slab graves of Mongolia and Songguk-ri site and Mahan, Oseok-ri's

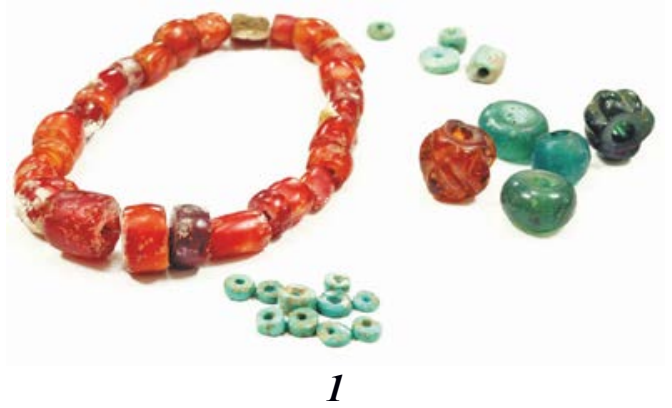

are exactly similar in shape, design, dimension, material and color (Fig. 36).

Figure 36. Stone beads and necklaces: 1. Slab grave, Mongolia [34];

2. Mahan, Oseok-ri, Seocheon [27]

7. Whetstones. Whetstones are a very important object for the household. Whetstones of Bronze and Early Iron Ages of Mongolia and Korea are exactly similar with respect to their function, shape, and material. But the difference is their attachment. Korean whetstones do not have a hole, while the Mongolian whetstones have a hole for the cord (Fig. 37).
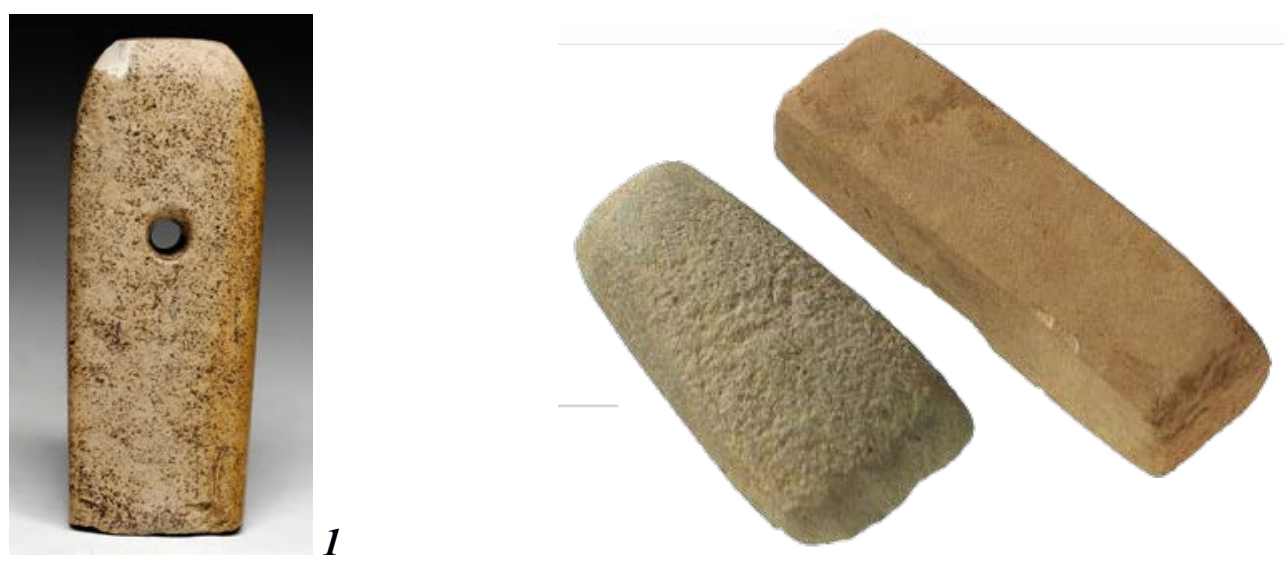

Figure 37. Whetstones: 1. Slab grave of Daram mountain, Eastern Mongolia;

2. Gubong-ri site, Buyeo [27] 


\section{CONCLUSIONS}

This research work can be summarized as follows. Evidently, there are some similarities and differences between archaeological monuments and artefacts of Bronze and Early Iron Ages of Mongolia and Korea. On the other hand, each set has its own special characteristics.

From the Bronze Age, people started to build huge tombs, settlements and began to engrave the rock for their deceased. It is not only in these two countries, people living in all other parts of the entire world were creating different kinds of huge monuments (Dolmens, tombs, settlements, stone structures, stone cists, pit-houses, and rock art), basing on their own specific religion, belief and ideology. Despite living in different cultures and far apart, people had similar knowledge, similar understanding, and similar rituals.

Similarities. One of the key similarities between the Bronze Age of these two countries (Korea and Mongolia) during the Bronze Age are Dolmen tombs of South Korea and "Sagsaishaped graves of Mongolia. Both exhibit a rectangular, square, and round shape of flat and stone covering tombs. Especially, some round shape of Dolmen's external and internal structures is very similar to the Sagsai-shaped graves. Another interesting and similar result, as mentioned above, is the internal structure of stone cist of Songguk-ri site in Buyeo; as well as some images (depictions of human, mask, animals, spirals, hoof seals) on petroglyphs in Korea and Mongolia. Some similarities are from archaeological finds (artefacts), mostly from graves and settlements. There are many objects that look either same or are very similar in terms of their shape, take for example, some potteries, beads, arrowheads, mirrors, whetstones, etc.

Differences. Obviously, there are many differences between these two countries' archaeological monuments and artefacts, which is also related with the geographical characteristics, natural materials (stones, wood) and the technologies for making them.

For the graves, the main difference are the human remains, which have been preserved very well on the Mongolia territory as compared to Korea. For example, in the Dolmens, a few objects (artefacts) were found, but in the Sagsai-shaped grave, almost no objects were found.

The other difference is that stone objects were used more often in the Korean Peninsula and are generally preserved well. Following are the differences in shape and materials of daggers. In Korea, well preserved polished stone and bronze daggers are totally different from those found in Mongolia, especially, the shape of the bronze daggers from Korea is totally different from the Mongolian bronze daggers. And one difference is the handle of bronze mirrors of Mongolia and Korea.

Characteristics. The main characteristic of these two countries is their geography and environment, which explains why natural material usage or processing are different from each other. For example, one of the characteristics of the Korean Peninsula is that the Buddhistic stone pagodas had developed much more than in Mongolia in the ancient times. This is obviously related to the reason mentioned above and also relate to the lifestyle of the Koreans (Mongolians were nomads while the Koreans were sedentary). The other big characteristic is the making of tombs of huge sizes in Korea and they are mostly made with earthen mound, on the other hand, in Mongolia, the tombs were made with stones with earthen (mixed) or only with stone mounds. Whatever the case, there are many similarities, differences, and specific characteristics between the two countries - Mongoia and Korea.

Acknowledgements. I would like to extend my sincere gratitude and appreciation to all my colleagues and people. In Buyeo and Korea, without which this research would not have been possible.

I wish to express my special thanks to the Korea Foundation. I feel honored to have been given the opportunity to take part in the Field Research program of the Korea Foundation. I was able to get acquainted with the various archaeological and architectural monuments, 
explore the collections of different museums in Korea, and also carry out comparative study of monuments, artefacts and archaeological materials of ancient nomads and ancient Korean states.

\section{REFERENCES}

1. Bale, M.T. and Ko Min-Jung., (2006). Craft Production and Social Change in Mumun Pottery Period Korea. Asian Perspectives, Vol. 45, No. 2. pp. 159-187.

2. Catalogue of Special Exhibition. Prehistoric village of Songguk-ri. (2017). Buyeo.

3. The report of Songguk-ri site VI. (2000). Puyõ National Museum.

4. Kyung Taek, K., Chi Young, J., Gun Il, L., Gun Sook, M., Hye Mi, J., Eun Ji, J. (2011). Research report of Archaeology Center. Vol. 3. Songguk-ri site VII: The 12th and 13th Field campaigns on Songguk-ri site in Buyeo. Buyeo.

5. Kyung Taek, K., Hyun Joo, S., Chi Young, J., Dong Hee, L. (2013). Research report of Archaeology Center. Vol. 8. Songguk-ri site VIII: The 14th Field campaign on Songguk-ri site in Buyeo. Buyeo.

6. Kyung Taek, K., Ki Sung, L., Gun Il, L., Dong Hee, L., Byung Wook, P. (2016). Research report of Archaeology Center. Vol. 13. Songguk-ri site X: The 16th and 17th Field campaigns on Songguk-ri site in Buyeo. Buyeo.

7. Kyung Taek, K., Ki Sung, Gun Il, L., Dong Hoon, J., Dong Hee, L., Byung Wook, P., Soo Young, K. (2017). Research report of Archaeology Center. Vol. 14. Songguk-ri site XI: The 18-20th Field campaigns on Songguk-ri site in Buyeo. Buyeo.

8. Turbat, Ts. (2016). Graves of Khemceg culture. Archaeological Relics of Mongolia. Ancient funeral monuments of Mongolia. Vol. III. Ulaanbaatar. pp. 3645.

9. Choi, Mong-Lyong. (2000). Origin and Diffusion of Korean Dolmens. Seoul. pp.18-31.
Finally, the author thanks the reviewers for their valuable comments and suggestions that significantly improved the earlier version of the manuscript.
10. Gantulga, J. (2016). Sagsai shaped graves. Archaeological Relics of Mongolia. Ancient funeral monuments of Mongolia. Vol. III. Ulaanbaatar. pp. 5871.

11. Korean rock art. (2015). Seoul. 10, 23-25, 26-29, 34-39, 57-67, 78-81, 82-85, 160163.

12. Daegokcheon Stream Petroglyphs 2010. https://whc.unesco.org/en/tentativelists/5 486/

13. Ho-Tae, J., Kim, (2013). Bangudae: Petroglyph Panels in Ulsan, Korea, in the Context of World Rock Art. (World Petroglyphs Research, Vol. I), Seoul, Hollym.

14. Francfort, P. (2013). The Bangudae rock art panel: A structural view. Bangudae: Petroglyphs panel in Ulsan, Korea, in the Context of World Rock Art. (World Petroglyphs Research, Vol. I), Seoul. pp. 99-110.

15. Ho-Tae, J., Myeong-su, J., Jong-Hoon, K., Yeon-ui, N., and Hyo-Jeong, Y. (2014). The Cheonjeon-ri Petroglyphs in Ulsan (Petroglyphs of Korea). Vol. I. Seoul: Hollym.

16. Francfort, P. (2015). The Cheonjeon-ri petroglyphs in Ulsan: A Native Art Historical View. in the Context of World Rock Art, (World Petroglyphs Research, vol. III), Jiyeon Kim (Dir.), Seoul, Hollym. pp. 23-49.

17. Kubarev, V.D., Tseveendorj, D., Jacobson E. (2005). Petroglyphs of Tsagaan Salaa and Baga Oigor (Mongolian Altai) / Novosibirsk. - 640 p.

18. Batbold, N. (2014). Research on Petroglyphs of the Mongolian Gobi. Ulaanbaatar.

19. Gantulga, J., Yeruul-Erdene Ch., Magail, J. (2018). Research on petroglyphs of 
Khuruugiin uzuur. Ulaanbaatar. 145, fig. 563.

20. Deer stones culture of Mongolian and Neighboring regions. (2018). Vol. I, II, Ulaanbaatar. 198, 166, no. 182; 161, no. 802

21. Gantulga, J. (2016). Seal themed images. Archaeological Relics of Mongolia. Rock art of Mongolia. Vol. IV. Ulaanbaatar. pp. 224-245.

22. Bale, M.T. (2018). Society and economy in Bronze Age Korea: A Western Archaeologist's Perspective. Seoul. 41, 46-47.

23. Kim Bumcheol, Kim Gyongtaek. (2017). An Experimental Attempt to Reconstruct the Relationship On the the royal tomb naming Dongmyoung and the between Floor Area and Number of Dwellers: With Special tombs of Pyoungyang Jinpari of Koguryo Reference to 'Songgukri-type' Huso Archaeology. No. 36. pp. 5-24, Tab. 2, fig. 4.

24. Kim Bumcheol. (2009). Where It Goes? Social Complexity and Political Economy in the Middle Bronze Age, Central-western Korea. The Review of Korean Studies Volume 12 Number 2 (June 2009). pp. 55-79, 1.

25. Dictionary of Korean Archaeology. (2005). Bronze Age. 76, 285, 482, 519.

26. Bangudae Petroglyphs. http://www.bangudaelove.com/Lang/EN G.php
27. Catalogue of Buyeo National Museum. (2015). Buyeo. 13, 96-97, Fig. 2, no. 050, 39, no.038, 47, no. 047, 65, no. 070.

28. Esin, Yu.N., Magail, J., Yeruul-Erdene, Ch., Gantulga, J. (2012). On the problem of clarifying the rock art of the Afanas'evo culture of Mongolia: new materials and approaches. Cultures of the steppe zone of Eurasia and their interaction with civilizations. Oct. 2012, St. Peterbourg, Vol. 1. pp. 205-211.

29. Tseveendorj, D. (1999). History of the ancient art of Mongolia. Ulaanbaatar. p. 242, 281, Tab. 119. 8, 158. 22.

30. Special Exhibition of Korean Prehistoric Culture. (1986). 10th Asian Games Arts Festival. Seoul National University Museum. 20, Fig. 11.

31. Turbat, Ts. (2016a). Neolithic and Eneolithic ceramic vessels. Archaeological Relics of Mongolia. Ancient ceramic potteries of Mongolia. Vol. VI. Ulaanbaatar. pp. 24-31, 31-32, Fig. 4.

32. Eiskurgan des Mongolischen Altai. Pazyryk kultur de Mongolie. (2016). Ulaanbaatar. 67, Fig. 19.

33. Tseveendorj, D. (2007). The culture of Chandmani. Ulaanbaatar.

34. Amartuvshin, Ch. (2016). Slab graves. Archaeological Relics of Mongolia. Ancient funeral monuments of Mongolia. Vol. III. Ulaanbaatar, pp. 112-125, Fig. 111. 